Hydrol. Earth Syst. Sci., 17, 3543-3560, 2013

www.hydrol-earth-syst-sci.net/17/3543/2013/

doi:10.5194/hess-17-3543-2013

(C) Author(s) 2013. CC Attribution 3.0 License.

\title{
Land use change effects on runoff generation in a humid tropical montane cloud forest region
}

\author{
L. E. Muñoz-Villers ${ }^{1}$ and J. J. McDonnell ${ }^{2,3}$ \\ ${ }^{1}$ Centro de Ciencias de la Atmósfera, Universidad Nacional Autónoma de México, Ciudad Universitaria, Distrito Federal, \\ México \\ ${ }^{2}$ Global Institute for Water Security, University of Saskatchewan, Saskatoon, Canada \\ ${ }^{3}$ University of Aberdeen, School of Geosciences, Aberdeen, UK
}

Correspondence to: L. E. Muñoz-Villers (lyssette.munoz@atmosfera.unam.mx)

Received: 1 April 2013 - Published in Hydrol. Earth Syst. Sci. Discuss.: 29 April 2013

Revised: 30 July 2013 - Accepted: 6 August 2013 - Published: 16 September 2013

\begin{abstract}
While tropical montane cloud forests (TMCF) provide critical hydrological services to downstream regions throughout much of the humid tropics, catchment hydrology and impacts associated with forest conversion in these ecosystems remain poorly understood. Here, we compare the annual, seasonal and event-scale streamflow patterns and runoff generation processes of three neighbouring headwater catchments in central Veracruz (eastern Mexico) with similar pedological and geological characteristics, but different land cover: old-growth TMCF, 20 yr-old naturally regenerating TMCF and a heavily grazed pasture. We used a $2 \mathrm{yr}$ record of high resolution rainfall and stream flow data (20082010 ) in combination with stable isotope and chemical tracer data collected for a series of storms during a 6-week period of increasing antecedent wetness (wetting-up cycle). Our results showed that annual and seasonal streamflow patterns in the mature and secondary forest were similar. In contrast, the pasture showed a $10 \%$ higher mean annual streamflow, most likely because of a lower rainfall interception. During the wetting-up cycle, storm runoff ratios increased at all three catchments (from 11 to $54 \%$ for the mature forest, 7 to $52 \%$ for the secondary forest and 3 to $59 \%$ for the pasture). With the increasing antecedent wetness, hydrograph separation analysis showed progressive increases of pre-event water contributions to total stormflow (from 35 to $99 \%$ in the mature forest, 26 to $92 \%$ in the secondary forest and 64 to $97 \%$ in the pasture). At all three sites, rainfall-runoff responses were dominated by subsurface flow generation processes for the majority of storms. However, for the largest and most intense storm (typically occurring once every $2 \mathrm{yr}$ ), sampled
\end{abstract}

under wet antecedent conditions, the event water contribution in the pasture (34\% on average) was much higher than in the forests (5\% on average), indicating that rainfall infiltration capacity of the pasture was exceeded. This result suggests that despite the high permeability of the volcanic soils and underlying substrate in this TMCF environment, the conversion of forest to pasture may lead to important changes in runoff generation processes during large and high intensity storms. On the other hand, our results also showed that $20 \mathrm{yr}$ of natural regeneration may be enough to largely restore the original hydrological conditions of this TMCF.

\section{Introduction}

The impact of land use change on hydrology is a major global research issue (Foley et al., 2005). Decreases in rainfall interception, transpiration and surface soil hydraulic conductivities associated with forest disturbance, and conversion to pasture or agricultural lands modifies the terrestrial water cycle (Chhabra et al., 2006), and may have significant effects on catchment water yields and streamflow dynamics (Germer et al., 2009; Roa-García et al., 2011; Scheffler et al., 2011; Zhang et al., 2001). In the tropics, these effects are amplified by the rapidity and extensiveness of the land cover change (Lambin et al., 2003).

There is substantial evidence that the conversion of forest to pasture or crops in the tropics is associated with an increase in annual streamflow totals because of the lower evapotranspiration of the replacement 
vegetation (see Bruijnzeel (2004) for an overview). However, at the same time, there have been reports of diminished streamflows during the dry season. The latter may occur when reductions in rainfall infiltration capacity due to soil compaction by cattle or agricultural machinery, and associated decreases in recharge of soil and groundwater reservoirs during the rainy season are large enough to offset the effect of lower evapotranspiration (Bruijnzeel, 2004). Nevertheless, to date, there are very few studies that have quantified the effects of land use change on runoff generation processes and seasonal flows in the humid tropics (Roa-García and Weiler, 2010; Roa-García et al., 2011).

In this respect, the effects of tropical montane cloud forest (TMCF) conversion on catchment hydrology are even less understood (Bruijnzeel et al., 2011). TMCFs are among the world's most valuable terrestrial ecosystems for biodiversity and provisioning of hydrological services to society (Hamilton et al., 1995; Tognetti et al., 2010; Zadroga, 1981). Nevertheless, dramatic degradation and loss of TMCFs worldwide have occurred over the last few decades (Scatena et al., 2010).

Because of the generally rapid growth of young secondary vegetation in the humid tropics, a quick return to predisturbance hydrology during forest regeneration following deforestation may be expected in these regions (Bruijnzeel, 2004). However, despite the fact that secondary forests are currently more widespread than old-growth forests in many tropical environments (Fox et al., 2000; Xu et al., 1999), the available information is extremely scarce (Hölscher et al., 2005), particularly in the case of TMCF (Bruijnzeel et al., 2011).

Much of our understanding of land use effects on runoff generation is derived from paired-catchment studies (mostly in temperate areas), i.e. controlled, experimental manipulations of the vegetation cover (Bosch and Hewlett, 1982; Brown et al., 2005; Bruijnzeel, 1990; Fritsch, 1993; Malmer, 1992; Peel, 2009). However, because most of the remaining forests in TMCF areas are officially protected by conservation laws (Muñoz-Piña, 2008; Scullion et al., 2011), experimental clearing for paired-catchment studies is generally not possible (Bruijnzeel, 2005). Hence, a common approach is to compare the hydrology of catchments with different land cover, but similar size, topography, soils, geology and climate (e.g. Germer et al., 2009; Moraes et al., 2006; MuñozVillers et al., 2012; Roa-García et al., 2011).

In Mexico, about $50 \%$ of the original TMCF area has been converted to other land uses (Cayuela et al., 2006; Challenger, 1998). In the highlands of central Veracruz (centraleastern Mexico), $26 \%$ of TMCF has been cleared for the establishment of pasture for cattle grazing and agricultural lands in the last $30 \mathrm{yr}$ (Muñoz-Villers and López-Blanco, 2008). In this study, we build upon previous work in the TMCF zone of central Veracruz and quantify the impacts of land use change on annual and seasonal rainfall-runoff patterns and stormflow generation processes. We do this by comparing three neighboring headwater catchments with similar pedological and geological properties, but different land use/vegetation cover: old-growth TMCF, 20 yr-old naturally regenerating TMCF, and a heavily grazed pasture. We use a $2 \mathrm{yr}$ record of high resolution rainfall and stream flow data (2008-2010) in combination with stable isotope and chemical tracer data collected for a series of storms during the 2009 wet season. We address the following research questions:

1. How does streamflow at annual, seasonal and event timescales compare among land covers?

2. How do runoff generation processes compare between the secondary and mature cloud forest?

3. What are the effects of forest conversion to pasture on runoff response in this TMCF environment?

\section{Materials and methods}

\subsection{Study site}

The research was carried out in three adjacent headwater catchments located between 2100 and $2500 \mathrm{~m}$ a.s.l. in the upper part of the cloud forest zone in central Veracruz, Mexico (Fig. 1). The catchments are situated in dissected mountainous terrain and are drained by first- or second-order perennial streams. Hillslopes are generally short and steep in the forested catchments, whereas somewhat less steep gradients characterize the pasture site (Table 1). Soils are classified as Umbric Andosols derived from volcanic ash (Campos Cascaredo, 2010; Van Osch, 2010) and having silt loam/silty clay loam as dominant textures. Surface soil in the forest sites are characterized by lower bulk densities and higher porosities (Marín-Castro, 2010; Muñoz-Villers et al., 2012) as compared to the pasture (Van Osch, 2010; Table 1). At all three sites, soil profiles are generally deeper at the hilltops compared to the near-stream areas. Soils in the forests are deeper (2-3 m; on average) and better developed (A1, A2, A3, AB, $\mathrm{Bw}, \mathrm{BwC}$ and $\mathrm{C}$ horizons) as compared to the pasture $(1.5 \mathrm{~m}$ on average; $\mathrm{A} 1, \mathrm{~A} 2, \mathrm{Bw}$ and $\mathrm{C}$ horizons) (Marín-Castro, 2010; D. Geissert, unpublished data). Field-saturated hydraulic conductivities $\left(K_{\mathrm{fs}}\right)$ measured at various depths along $1.5 \mathrm{~m}$ soil profiles using a constant-head permeameter show decreases from $1000 \mathrm{~mm} \mathrm{~h}^{-1}$ at $0.1 \mathrm{~m}^{2} 4 \mathrm{~mm} \mathrm{~h}^{-1}$ at $1.5 \mathrm{~m}$ soil depth in the mature forest (Karlsen, 2010), whereas in the pasture $K_{\mathrm{fs}}$ range between $30 \mathrm{~mm} \mathrm{~h}^{-1}$ at $0.2 \mathrm{~m}$ to $7 \mathrm{~mm} \mathrm{~h}^{-1}$ at $1.5 \mathrm{~m}$ depth (Van Osch, 2010). The soils are underlain by permeable, moderately weathered andesitic breccias, underlain, in turn, by permeable saprolite that has been weathered from fractured andesitic-basaltic bedrock.

The mature forest (henceforth MAT) is an old-growth lower montane cloud forest (LMCF) with relatively low disturbance. The overstory of this forest is dominated by Quercus ocoteoifolia, Clethra macrophylla, Parathesis 
Table 1. Topographic and soil physical characteristics of the three study catchments. Where available, the standard deviation (SD) is provided.

\begin{tabular}{|c|c|c|c|}
\hline & MAT & SEC & PAS \\
\hline Area $(h a)^{\mathrm{a}, \mathrm{b}}$ & 25 & 12 & 10 \\
\hline Mean slope $\left({ }^{\circ}\right)^{\mathrm{a}, \mathrm{b}}$ & 33 & 31 & 18 \\
\hline Mean slope length $(\mathrm{m})^{\mathrm{a}, \mathrm{b}}$ & 123 & 105 & 68 \\
\hline Length of river channel $(\mathrm{km})^{\mathrm{a}, \mathrm{b}}$ & 1.2 & 0.7 & 0.6 \\
\hline Mean slope of river channel $\left({ }^{\circ}\right)^{\mathrm{a}, \mathrm{b}}$ & 20 & 17 & 15 \\
\hline Aspect $^{\mathrm{a}, \mathrm{b}}$ & NW-SE & W-E & NW-SE \\
\hline Mean soil bulk density $\left(\rho_{\mathrm{b}}\right)^{\mathrm{c}, \mathrm{d}}\left(\mathrm{g} \mathrm{cm}^{-3}\right)$ & $0.25 \pm 0.17$ & $0.45 \pm 0.11$ & $0.48 \pm 0.05$ \\
\hline Mean soil porosity $\mathrm{c}, \mathrm{d}$ & $0.89 \pm 0.08$ & $0.89 \pm 0.03$ & $0.81 \pm 0.02$ \\
\hline Surface soil saturated hydraulic conductivity $\left(K_{\mathrm{fs}}\right)^{\mathrm{a}, \mathrm{e}}\left(\mathrm{mm} \mathrm{h}^{-1}\right)$ & $777 \pm 931$ & $615 \pm 690$ & $30 \pm 14$ \\
\hline
\end{tabular}

\footnotetext{
a Muñoz-Villers (2008) and Muñoz-Villers et al. (2012); for the MAT and SEC catchments.

b L. E. Muñoz-Villers, unpublished data; for the PAS catchment.

c Marín-Castro (2010); the average and SD of the values at $0.05 \mathrm{~m}$ depth for the MAT and SEC catchments.

${ }^{\mathrm{d}} \mathrm{D}$. Geissert, unpublished data; the average and SD of the values at $0.1 \mathrm{~m}$ depth for the PAS catchment.

e Van Osch (2010); the average and SD of the values at $0.2 \mathrm{~m}$ depth for the PAS catchment.
}

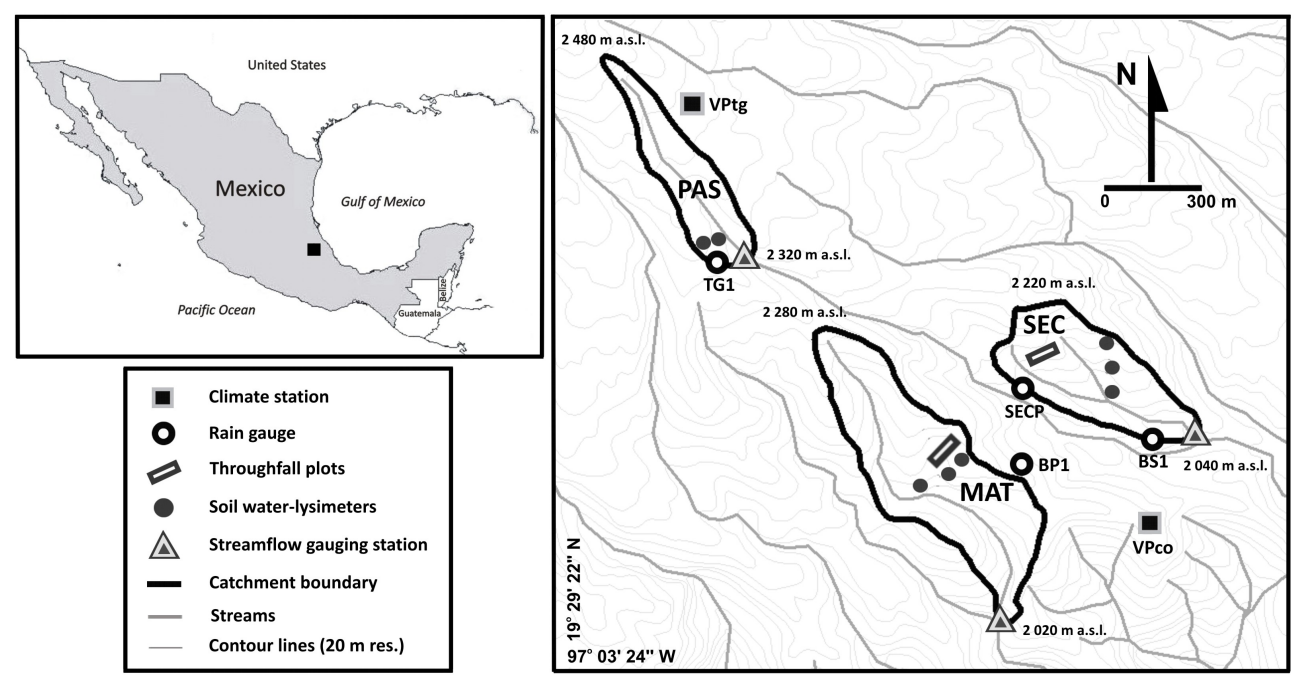

Fig. 1. Location of the study area in central Veracruz, Mexico, and maps of the study catchments showing the instrumentation and experimental sites. Sources: Topographic data from the Instituto Nacional de Estadística, Geografía e Informática (INEGI;1993) (1:250 000 scale: Mexico) and INEGI (2000) (1:50 000 scale: Mexico). Catchment boundaries of the forests from Muñoz-Villers (2008).

melanosticta and Alchornea latifolia (García-Franco et al., 2008). The $20 \mathrm{yr}$-old regenerating forest (henceforth SEC) is a mixture of equal proportions of LMCF recovered naturally from a wildfire in 1990 and a pasture land that was abandoned around the same time. Alnus jorullensis is the overstory species while Clethra macrophylla, Alchornea latifolia and Miconia glaberrima characterize the mid- and understory. More details on the vegetation characteristics of the MAT and SEC can be found in García-Franco et al. (2008) and Muñoz-Villers et al. (2012).

The original vegetation in the pasture (henceforth PAS) catchment was LMCF, which was cleared approximately $70 \mathrm{yr}$ ago (local inhabitants, personal communication). Since then, the pasture has been heavily grazed by goats, sheep and horses. The dominant grass species are Axonopus compressus (Sw.) P. Beauv. and Alchemilla pectinata Kunth, with an average height of about $20 \mathrm{~mm}$ (L.E. Muñoz-Villers, unpublished data). Approximately $10 \%$ of the PAS is covered by Baccaris conferta, a secondary perennial shrub species of about $1.2 \mathrm{~m}$ height; once a year, different parts of this shrub are burned to establish temporal croplands (mostly maize and beans).

The climate at the study site is classified as temperate humid with abundant rains during the summer (Köppen classification modified by Garcia, 1988). Average annual rainfall at this site was $3061 \pm 414(\mathrm{SD}) \mathrm{mm}$ over the period 2005-2010 (F. Holwerda, unpublished data), of which $80 \%$ typically fell as convective storms during the wet season (May-October), when the region is under the influence of the easterly trade wind flow. Dry season (November-April) rainfall is generally associated with cold fronts and characterized by light rains and/or drizzle (Holwerda et al., 2010; 
Muñoz-Villers et al., 2012). Monthly mean temperatures are about 15.4 and $13.4{ }^{\circ} \mathrm{C}$ on average for the wet and dry seasons, respectively (Holwerda et al., 2010).

\subsection{Hydrometeorological measurements}

Rainfall was measured at one site in the MAT (BP1) and PAS (TG1) catchments, and at two sites in the SEC (SECP, BS1) catchment (Fig. 1). Additionally, two rain gauges were installed at the weather stations (labeled "VPco" and "VPtg" in Fig. 1). The rain gauges used were of the type ARG100 (Environmental Measurements), Casella CEL and RG2M (Onset) (all with a resolution of $0.2 \mathrm{~mm}$ ). The signals from the stand-alone rain gauges were stored using custom-built (VU University, Amsterdam) and HOBO pendant event (Onset) loggers, whereas those from the gauges at the weather stations were recorded with CR1000 data loggers (Campbell Scientific). All gauges were dynamically calibrated to account for the variable error associated with the loss of water during bucket rotation (Calder and Kidd, 1978).

Streamflow was measured using V-notch weirs at the catchment outlets $\left(90^{\circ}\right.$ angle for the MAT and $53.6^{\circ}$ for the SEC and PAS). Water levels were registered every $2 \mathrm{~min}$ using Schlumberger LT F15/M5 water level sensors paired with F5/M1.5 barometric pressure recorders. Water levels were converted to streamflow $\left(\mathrm{L} \mathrm{s}^{-1}\right)$ using the experimental stage-discharge relationship for these weirs (Kindsvater and Carter, 1957), calibrated with field-derived rating curves generated via volumetric- and salt dilution measurements of discharge (c.f. Hongve, 1987). Further details on instrumentation and calibration procedures can be found in MuñozVillers et al. (2012). Rainfall and streamflow measurements in the MAT and SEC started in July 2005, whereas data collection in the PAS began in June 2008.

\subsection{Hydrologic metrics analysis}

To intercompare the annual and seasonal hydrological regimes of the three catchments, basic hydrologic statistics and several indices were calculated using hourly (denoted by subscript h) and daily (denoted by the subscript d) streamflow and rainfall data $\left(Q_{\mathrm{h}}, Q_{\mathrm{d}}, P_{\mathrm{h}}\right.$ and $P_{\mathrm{d}}$, respectively; all in units of $\mathrm{mm}$ ) collected from 1 June 2008 to 31 May 2010. For each catchment, the following parameters were calculated using the daily discharge record $\left(Q_{\mathrm{d}}\right)$ : mean annual flow (MAF), mean runoff ratio (MRR), coefficient of variation of stream discharge $\left(\mathrm{CV}_{\mathrm{Q}}\right)$, flow duration curve (FDC) and master recession curve (MRC).

The MAF $\left[\mathrm{mm} \mathrm{day}^{-1}\right]$ was determined by calculating the arithmetic mean of all the individual daily flows recorded over the 2 yr study period. The MRR [-] was calculated as the ratio of total streamflow to total precipitation (Olden and Poff, 2003):

$\operatorname{MRR}=\frac{\sum Q_{\mathrm{d}}}{\sum P_{\mathrm{d}}}$.
The FDC describes the distribution of probabilities of streamflow being greater than or equal to a specified magnitude plotted on a semi-log scale. As a measure of flow variability, the slope of the FDC ( $\left.\mathrm{S}_{\mathrm{FDC}}[-]\right)$ between the 5th and 95th streamflow percentiles was calculated using the method of Zhang et al. (2008) modified by Sawicz et al. (2011):

$\mathrm{S}_{\mathrm{FDC}}=\frac{\ln \left(Q_{5}\right)-\ln \left(Q_{95}\right)}{0.95-0.05}$.

Additionally, the mean annual high (MAHF [mm]) and low flow (MALF [mm]) were calculated as the mean of the 1st and 99th percentiles of the FDC, respectively.

The MRC was constructed from daily dry season streamflow data using the matching strip method (Toebes and Strang, 1964). The MRC was described using linear reservoir theory (Chapman, 1999):

$Q_{\mathrm{d}}=Q_{0} \exp (-t / \tau)=Q_{0} k^{t}$,

where $Q_{0}$ and $Q_{\mathrm{d}}$ are the flows $\left(\mathrm{mm} \mathrm{day}^{-1}\right)$ at time 0 and $t$ (days), respectively, $\tau$ is the turnover time of the groundwater storage (days) and $k$ is the recession constant. The initial discharge value $Q_{0}$ and recession constant $k$ were obtained from linear regression analysis using log-transformed discharge data. Since all MRCs showed departures from linearity towards the end of the recession, indicating catchment leakage (Fig. 2; c.f. Chapman, 1999), the baseflow recession parameters $Q_{0}$ and $k$ (Eq. 3) were obtained from that portion of the MRC where the relationship between $\log \left(Q_{d}\right)$ and $t$ was linear (Muñoz-Villers et al., 2012).

Hourly data were used to graphically separate streamflow into quickflow ( $Q_{\mathrm{qf}}$; the direct flow in response to a rainfall event) and baseflow ( $Q_{\mathrm{bf}}$; the delayed flow from storage) following the approach of Hewlett and Hibbert (1967). The hydrograph separation was performed using a slope constant of $0.030 \mathrm{~mm} \mathrm{~h}^{-1}$ (Muñoz-Villers, 2008). Storms were defined as periods with more than $0.2 \mathrm{~mm}$ of rainfall $\left(P_{\mathrm{ev}}\right)$, separated by a dry period of at least $3 \mathrm{~h}$ (cf. Gash, 1979).

The Baseflow Index (BFI [-]) was calculated from the inferred values of $Q_{\mathrm{bf}}$ and measured $Q_{\mathrm{h}}$ using (Arnold et al., 1999):

$\mathrm{BFI}=\frac{\sum Q_{\mathrm{bf}}}{\sum Q_{\mathrm{h}}}$.

Finally, the Richards-Baker Flashiness Index (FI [-]) was calculated as a metric of the frequency and rapidity of shortterm changes in runoff values (catchment responsiveness). The FI index was calculated as the sum of the absolute values of hour-to-hour changes in $Q_{\mathrm{h}}$ divided by the sum of the hourly discharges (Baker et al., 2004):

$\mathrm{FI}=\frac{\sum_{i=1}^{\mathrm{n}}\left|Q_{\mathrm{h}, i}-Q_{\mathrm{h}, \mathrm{i}-1}\right|}{\sum_{\mathrm{i}=1}^{\mathrm{n}} Q_{\mathrm{h}, \mathrm{i}}}$, 

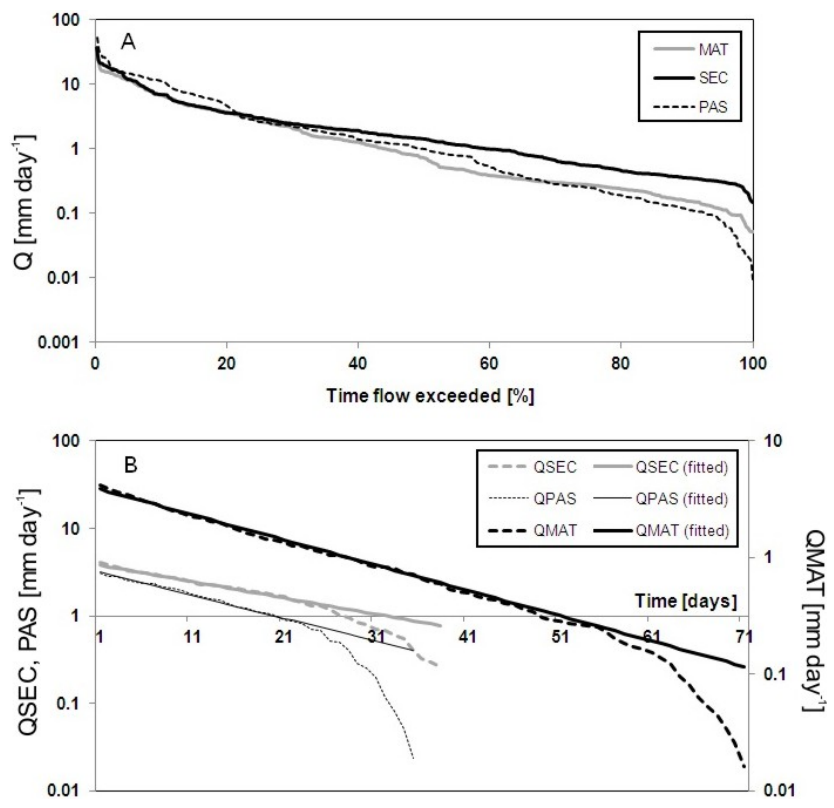

Fig. 2. (a) Flow duration curves for each of three study catchments; and (b) master recession curves (dashed lines) and fitted recession equations (solid lines) of the form $Q_{\mathrm{t}}=Q_{0} k^{\mathrm{t}}$ (see text for further explanation). Note that data are plotted on a semi-logarithmic scale.

where $Q_{\mathrm{h}, i}$ and $Q_{\mathrm{h}, i-1}$ are the hourly discharges of hour $i$ and hour $i-1$, respectively.

\subsection{Storm runoff analysis}

\subsubsection{Stream event responses}

To assess stream response to precipitation and the influence of antecedent wetness conditions on runoff generation processes in the study catchments, several storm events were examined during a 6-week period (1 August to 14 September 2009) of increasing antecedent wetness. For each storm, the following parameters were calculated: total rainfall $\left(P_{\mathrm{ev}}[\mathrm{mm}]\right)$, maximum hourly rainfall intensity $\left(I_{60} \max \right.$ $\left.\left[\mathrm{mm} \mathrm{h}^{-1}\right]\right)$, event duration $\left(T_{\mathrm{p}}[\mathrm{h}]\right)$, the ratio between total runoff and rainfall $\left(Q_{\mathrm{t}} / P_{\mathrm{ev}}\right)$, the ratio between quickflow and event rainfall $\left(Q_{\mathrm{qf}} / P_{\mathrm{ev}}\right)$, peak discharge $\left(Q_{\text {peak }}\left[\mathrm{mm} \mathrm{h}^{-1}\right]\right)$ and the antecedent precipitation index $\left(\mathrm{API}_{7}[\mathrm{~mm}]\right)$, calculated as the sum of daily rainfall amounts for the 7 days prior to the rainfall event weighted by the recession constant $k$ (Viessman et al., 1989). Furthermore, the lag time, defined as the time between peak rainfall and peak discharge, and the time to peak, defined as the time between the onset of storm discharge and peak discharge (Mosley, 1979) were calculated. For the latter analysis, 10 min rainfall and streamflow data were used.

\subsubsection{Storm water sampling and collection}

To identify the sources and pathways of stormflow in the three study catchments, samples of rainfall, throughfall, soil and stream water were collected for as many as storms as possible during the 6-week wetting-up cycle period for water isotope $\left(\delta^{2} \mathrm{H}\right.$ or $\left.\delta^{18} \mathrm{O}\right)$ and chemical (electrical conductivity, EC) analysis. These samples were then used as end-members and tracers for storm hydrograph separation (HS) analysis (see Sect. 2.4.4).

Because wet season rainfall in this area is primarily of convective origin (Báez et al., 1997), this type of rain-producing system was particularly targeted for the rainfall-runoff sampling. The following criteria were used to decide whether a storm event sampled was considered for isotope analysis: (1) rainfall had to be greater than $20 \mathrm{~mm}$ to ensure a substantial rise in the stream hydrograph, and (2) the sampling should have covered the entire stream hydrograph and include at least one baseflow sample before the storm started.

Rainfall was collected in $5 \mathrm{~mm}$ increments using two passive sequential samplers (Kennedy et al., 1979). One of the samplers was paired with the rain gauge located in between the MAT and SEC catchments (SECP; Fig 1), and the other one was placed next to the rain gauge at the outlet of the PAS catchment (TG1). At the same locations, bulk samples of rainfall were collected using a rainwater sampler consisting of a $95 \mathrm{~mm}$ diameter funnel assembled to a $40 \mathrm{~mm}$ diameter and $400 \mathrm{~mm}$ long transparent collection tube. The tube contained a float to minimize evaporation. The rain gauge was inserted in $75 \mathrm{~mm}$ diameter PVC pipe wrapped by bubble foil insulation to protect the collected water against direct sunlight and minimize temperature variations. No attempt was made to collect sequential samples of throughfall because of the difficulties involved in getting a representative sample due to the large spatial variability of throughfall in tropical forests (e.g. Holwerda et al., 2006). However, bulk samples of throughfall in the MAT and SEC were collected for comparison with rainfall using ten collectors distributed randomly in each forest. Further details on rainwater and throughfall collection methods can be found in MuñozVillers and McDonnell (2012).

Stream water was collected during the storms using 3700C automatic water samplers (Teledyne ISCO, Inc., USA) installed at the streamflow gauging stations (Fig. 1). The three samplers were programmed to start sampling at the same frequency and time, approximately 1 to $2 \mathrm{~h}$ before the storm was expected to initiate (to include at least one sample of stream baseflow). In addition, in each catchment grab samples of baseflow were collected once a week.

Soil water was collected prior to the storms from porous cup lysimeters (Soil Moisture Equipment, Corp., USA), using a suction of about $60 \mathrm{kPa}$. In the MAT and SEC, the lysimeters were installed at three topographic locations (Fig. 1). At the ridge top and midslope positions, four lysimeters were installed at $0.3,0.6,0.9$ and $1.2 \mathrm{~m}$ depth, meanwhile 
three lysimeters were installed in the near-stream valley at $0.3,0.6$ and $0.9 \mathrm{~m}$ depth. In the PAS, lysimeters were installed in the midslope and near the stream at $0.3,0.6$ and 0.9 m depth.

\subsubsection{Sample analysis}

Samples for water isotope analysis were stored in $30 \mathrm{ml}$ borosilicate glass vials with a polycone sealing cap to prevent evaporation. The samples were analyzed for $\delta^{2} \mathrm{H}$ and $\delta^{18} \mathrm{O}$ on a laser liquid-water isotope spectrometer (Version 2, Los Gatos Research, Inc.) at the Hillslope and Watershed Hydrology Lab at Oregon State University, USA. The isotope values of $\delta^{2} \mathrm{H}$ and $\delta^{18} \mathrm{O}$ are expressed in permil (\%o) relative to Vienna Standard Mean Ocean Water (VSMOW). The precision of $\delta^{2} \mathrm{H}$ and $\delta^{18} \mathrm{O}$ measurements was 0.3 and $0.1 \%$, respectively.

Measurements of electrical conductivity (EC) were obtained in situ for each water sample collected for isotope analysis using a portable EC meter (Oakton, Model 300 Series).

\subsubsection{Isotope-chemical hydrograph separation}

In addition to the graphical HS analysis, a one-tracer twocomponent HS analysis was conducted to separate storm runoff into its pre-event and event water sources using the following mass balance equation (Pinder and Jones, 1969; Sklash and Farvolden, 1979):

$Q_{\mathrm{t}} C_{\mathrm{t}}=Q_{\mathrm{p}} C_{\mathrm{p}}+Q_{\mathrm{e}} C_{\mathrm{e}}$,

where $Q_{\mathrm{t}}, Q_{\mathrm{p}}$ and $Q_{\mathrm{e}}$ refer to total streamflow, pre-event and event water volumes, respectively, and $C_{\mathrm{t}}, C_{\mathrm{p}}$ and $C_{\mathrm{e}}$ are the corresponding $\delta^{2} \mathrm{H}$ or $\delta^{18} \mathrm{O}$ isotope ratios. The average of the tracer concentrations in the baseflow samples taken prior to the storm was taken as representative of $C_{\mathrm{p}}$ (Sklash and Farvolden, 1979). $C_{\mathrm{e}}$ at a specific time was calculated as the weighted mean of the isotopic composition of the rainfall samples up to that time (McDonnell et al., 1990). Furthermore, a two-tracer three-component HS analysis was performed to examine the contributions of soil water and groundwater (both components of pre-event water) to storm runoff, using the measured $\delta^{2} \mathrm{H}$ or $\delta^{18} \mathrm{O}$ isotope ratios and EC concentrations (Ogunkoya and Jenkins, 1993):

$Q_{\mathrm{t}} C_{\mathrm{t}}=Q_{\mathrm{e}} C_{\mathrm{e}}+Q_{\mathrm{s}} C_{\mathrm{s}}+Q_{\mathrm{g}} C_{\mathrm{g}}$,

where $Q_{\mathrm{t}}, Q_{\mathrm{e}}, Q_{\mathrm{s}}$ and $Q_{\mathrm{g}}$ are the assumed components of total storm runoff (streamflow, event, soil and ground water volumes, respectively), and $C_{\mathrm{t}}, C_{\mathrm{e}}, C_{\mathrm{s}}$ and $C_{\mathrm{g}}$ are the corresponding tracer concentrations. In this study, $C_{\mathrm{s}}$ was calculated as the average value of the tracer concentrations across soil depths and topographic positions in the catchment. $C_{\mathrm{g}}$ was assumed equal to the average tracer concentration of baseflow measured prior to the storm (i.e. $C_{\mathrm{p}}$ ). The uncertainty associated in the calculation of the pre-event fractions
Table 2. Coefficient of variation of stream discharge $\left(\mathrm{CV}_{Q}\right)$, mean annual high flow (MAHF) and mean annual low flow (MALF; all expressed in mm) plus mean annual flow (MAF $\left[\mathrm{mm} \mathrm{day}^{-1}\right]$ ) and slope of the flow duration curve $\left(\mathrm{S}_{\mathrm{FDC}}[-]\right)$ for each of the study catchments over the period June 2008-May 2010.

\begin{tabular}{llll}
\hline & MAT & SEC & PAS \\
\hline MAF ( \pm SD) & $3.5(5.0)$ & $3.9(5.2)$ & $4.3(5.6)$ \\
CV $_{Q}$ & 1.4 & 1.3 & 1.3 \\
SFDC $[-]_{\text {MAHF ( } \pm \text { SD) }}$ & 4.9 & 4.1 & 5.4 \\
MALF ( \pm SD) & $0.07(0.02)$ & $0.21(0.05)$ & $0.02(0.01)$ \\
\hline
\end{tabular}

was quantified using the error propagation technique proposed by Genereux (1998) at the 0.05 confidence level.

\section{Results}

\subsection{Rainfall characteristics}

During the two-year study period (1 June 200831 May 2010), mean annual precipitation $(P)$ was very similar between the forest catchments $(3371 \mathrm{~mm}$ for the MAT and $3326 \mathrm{~mm}$ for the SEC) and only slightly lower in the pasture $(3159 \mathrm{~mm})$. Annual $P$ was $3476 \mathrm{~mm}$ in $2008 / 2009$ and $3095 \mathrm{~mm}$ in 2009/2010 (averages across all sites). On average, $82 \%$ of the annual $P$ fell during the wet season (May-October). Average monthly precipitation during the rainy season $(455 \pm 239$ (SD) $\mathrm{mm}$ ) was five times that observed during the dry season $(93 \pm 47 \mathrm{~mm})$. Average daily rainfall was $15 \pm 20 \mathrm{~mm}$ (range: $0-111 \mathrm{~mm}$ ) for the wet season versus $3 \pm 7 \mathrm{~mm}$ (range: $0-56 \mathrm{~mm}$ ) for the dry season across all sites.

\subsection{Streamflow and hydrologic metrics}

During the study period, mean annual streamflow was higher in the pasture (1554 mm, on average) compared to the MAT $(1268 \mathrm{~mm})$ and SEC $(1414 \mathrm{~mm})$. The higher streamflow in the PAS was also reflected in the value of the mean runoff ratio (MRR), which was 0.50 on average for the PAS versus 0.38 and 0.43 for the MAT and SEC, respectively. In each catchment, baseflow $\left(Q_{\mathrm{bf}}\right)$ accounted for the majority of streamflow (91, 87 and $93 \%$ in the MAT, SEC and PAS, respectively); expressed as a percentage of $P, Q_{\mathrm{bf}}$ was $34 \%$ for the MAT, $37 \%$ for the SEC and $46 \%$ for the PAS. Total quickflow $\left(Q_{\mathrm{qf}}\right)$ was very low in the three studied catchments; expressed as a percentage of $P, Q_{\mathrm{qf}}$ was 4,6 and $4 \%$ in the MAT, SEC and PAS, respectively.

The mean monthly flow during the wet season was highest in the PAS $(215 \pm 168$ (SD) $\mathrm{mm})$, followed by SEC $(195 \pm 148 \mathrm{~mm})$ and then by MAT $(183 \pm 141 \mathrm{~mm})$. Stream flow during the dry season consisted almost entirely of baseflow in each study catchment; mean monthly streamflow 
for this period was very similar for the PAS $(44 \pm 35 \mathrm{~mm})$ and SEC $(41 \pm 18 \mathrm{~mm})$, but considerably lower for the MAT $(28 \pm 19 \mathrm{~mm})$.

Although the mean annual flow (MAF) was higher in the PAS compared to the forests, the three catchments displayed similar variations around their mean values $\left(\mathrm{CV}_{Q}\right.$; Table 2$)$.

Flow duration curve (FDC) analysis showed that the greatest variability in hydrological regime occurred in the PAS, showing the highest and lowest discharge above the Q5 and below Q95, respectively, as well as the steepest slope ( $\mathrm{S}_{\mathrm{FDC}}$; Fig. 2, Table 2). The SEC showed the flattest FDC, with discharges that were greater than those observed in MAT and PAS below Q25. In agreement with the FDC analysis, mean annual high flows (MAHF) were higher in the pasture in comparison to the forests (Table 2), meanwhile mean annual low flows (MALF) were the lowest in the PAS and highest in the SEC.

In all three catchments, Baseflow Indexes (BFIs) were generally high $(91 \%, 89 \%$ and $95 \%$ for the MAT, SEC and PAS, respectively), as well as the recession constants $(k)$ obtained from the master recession curves $(0.95,0.96$ and 0.94 , respectively), meanwhile corresponding Flashiness Indexes were very low $(0.09,0.11$ and 0.07 , respectively). All this reflects stable flow regimes, with a dominance of groundwater in streamflow.

\subsection{The 2009 wetting-up cycle}

\subsubsection{Catchment event response}

During the 6-week wetting-up cycle (1 August-14 September 2009), total rainfall in each of the three catchments was approximately $1200 \mathrm{~mm}$, delivered by 46 discrete rainfall events in the forests and 43 events in the pasture. The forest streams responded to 42 of the 46 storms identified. Due to the temporary absence of the water level recorder in the PAS, runoff data were available for only 36 of the 43 storms identified, from which 35 produced a response in the stream. Note that the rainfall-runoff analysis presented below was performed using only those storms for which data from all three sites were available.

During the 6-week wetting-up cycle, the seven-day antecedent precipitation index $\left(\mathrm{API}_{7}\right)$ increased from 9 to $319 \mathrm{~mm}$, indicating a shift from relatively dry to very wet conditions. There was no statistically significant difference $(p>0.05)$ between rainfall event amounts $\left(P_{\mathrm{ev}}\right)$ recorded at the three sites. $P_{\mathrm{ev}}$ ranged between 1 and $118 \mathrm{~mm}(28 \pm 24 \mathrm{~mm}$; mean $\pm \mathrm{SD})$, maximum hourly intensities $\left(I_{60 \mathrm{max}}\right)$ from 0.8 to $68 \mathrm{~mm} \mathrm{~h}^{-1}(16 \pm 15 \mathrm{~mm})$ and event durations $\left(T_{\mathrm{p}}\right)$ between 1 and $15 \mathrm{~h}(5 \pm 3 \mathrm{~h})$.

It was observed that nearly equal rain event inputs produced very different streamflow responses in the pasture as compared to the forests. Conversely, the forest streams generated remarkably similar rainfall-runoff responses, as shown in Fig. 3. In the first half of the wetting-up cy- cle (1-25 August 2009), the pasture produced average rainfall-runoff ratios $\left(Q_{\mathrm{t}} / P_{\mathrm{ev}}\right)$ that were significantly lower $(0.09 \pm 0.08(\mathrm{SD}) ; p \leq 0.001)$ than those generated by the MAT $(0.19 \pm 0.10)$ and SEC $(0.17 \pm 0.07)$. Corresponding quickflow event ratios $\left(Q_{\mathrm{qf}} / P_{\mathrm{ev}}\right)$ were $0.03 \pm 0.03$ and $0.03 \pm 0.04$ for the MAT and SEC, respectively, whereas they were less than 0.01 in the pasture. In this same period, the pasture showed a mean peak discharge $\left(0.2 \mathrm{~mm} \mathrm{~h}^{-1}\right)$ that was half those observed in the MAT $\left(0.4 \mathrm{~mm} \mathrm{~h}^{-1}\right)$ and in the SEC $\left(0.4 \mathrm{~mm} \mathrm{~h}^{-1}\right)$. Corresponding values of peak discharge variance $\left(\sigma^{2}\right)$ for the PAS $\left(0.1 \mathrm{~mm} \mathrm{~h}^{-1}\right)$ were about nine times lower than those for the MAT $\left(0.9 \mathrm{~mm} \mathrm{~h}^{-1}\right)$ and SEC $\left(0.9 \mathrm{~mm} \mathrm{~h}^{-1}\right)$. In contrast, in the second half of the wetting-up period (from 25 August onwards), the pasture showed higher $Q_{\mathrm{t}} / P_{\mathrm{ev}}$ ratios $(0.42 \pm 0.14)$ than the forests $(0.30 \pm 0.13$ and $0.39 \pm 0.12$ for the MAT and SEC, respectively). Although mean peak discharge and variance were higher for all three sites compared to the first half of the wetting-up period, the PAS showed this time higher values (mean peak discharge $\pm \sigma^{2}: 2 \pm 10.2 \mathrm{~mm} \mathrm{~h}^{-1}$ ) as compared to the MAT $\left(1.3 \pm 2.3 \mathrm{~mm} \mathrm{~h}^{-1}\right)$ and $\operatorname{SEC}\left(1.7 \pm 3.2 \mathrm{~mm} \mathrm{~h}^{-1}\right)$.

Over the entire wetting-up cycle, the PAS showed the shortest lag times (range: $10-90 \mathrm{~min}$ ) and time to peak discharges (range: 10-150 min) as compared to the MAT (20$140 \mathrm{~min}, 20-280 \mathrm{~min}$, respectively) and SEC (10-140 min, 30-260 min, respectively). The lag time distribution of the MAT differed significantly from the PAS $(p \leq 0.001)$ and SEC ( $p=0.012)$, meanwhile no significant differences were found between the PAS and SEC ( $p \geq 0.05)$. The distribution of time to peak discharges was not statistically different among sites $(p \geq 0.05)$. For all sites, peak flows correlated well with $P_{\mathrm{ev}}\left(r^{2}=0.72\right.$ on average $)$ and $I_{60 \max }\left(r^{2}=0.75\right)$, yet poorly with $\mathrm{API}_{7}\left(r^{2} \leq 0.3\right)$. Lag times and times to peak discharge showed generally low correlations with $P_{\mathrm{ev}}$ $\left(r^{2} \leq 0.2\right.$ on average), $I_{60 \text { max }}\left(r^{2} \leq 0.3\right)$ and $\mathrm{API}_{7}\left(r^{2} \leq 0.2\right)$.

\subsubsection{Selected storms for hydrograph separation}

A total of nine storms out of thirteen sampled during the wetting-up cycle fulfilled the earlier defined criteria (Sect. 2.4.2). For the MAT and SEC, six out of these nine events showed enough difference between event and preevent tracer concentrations to perform storm hydrograph separation. Due to the temporary absence of the water level recorder in the PAS (see Sect. 3.2), three out of the nine storms had to be discarded; from the six storms remaining, five were suitable for HS analysis.

Characteristics of the six storms analyzed in detail are presented in Table 3. In general, the storms started during the second half of the afternoon or early evening (between 15:00 and 19:00 LT). Average storm size, duration and maximum intensity were $46 \mathrm{~mm}, 3 \mathrm{~h}$ and $29 \mathrm{~mm} \mathrm{~h}^{-1}$, respectively.

For the storms, $Q_{\mathrm{t}} / P_{\mathrm{ev}}$ ratios ranged from 0.11 to 0.54 in the MAT, from 0.07 to 0.52 in the SEC and from 0.03 to 0.59 in the PAS, and showed a progressive increase as antecedent 

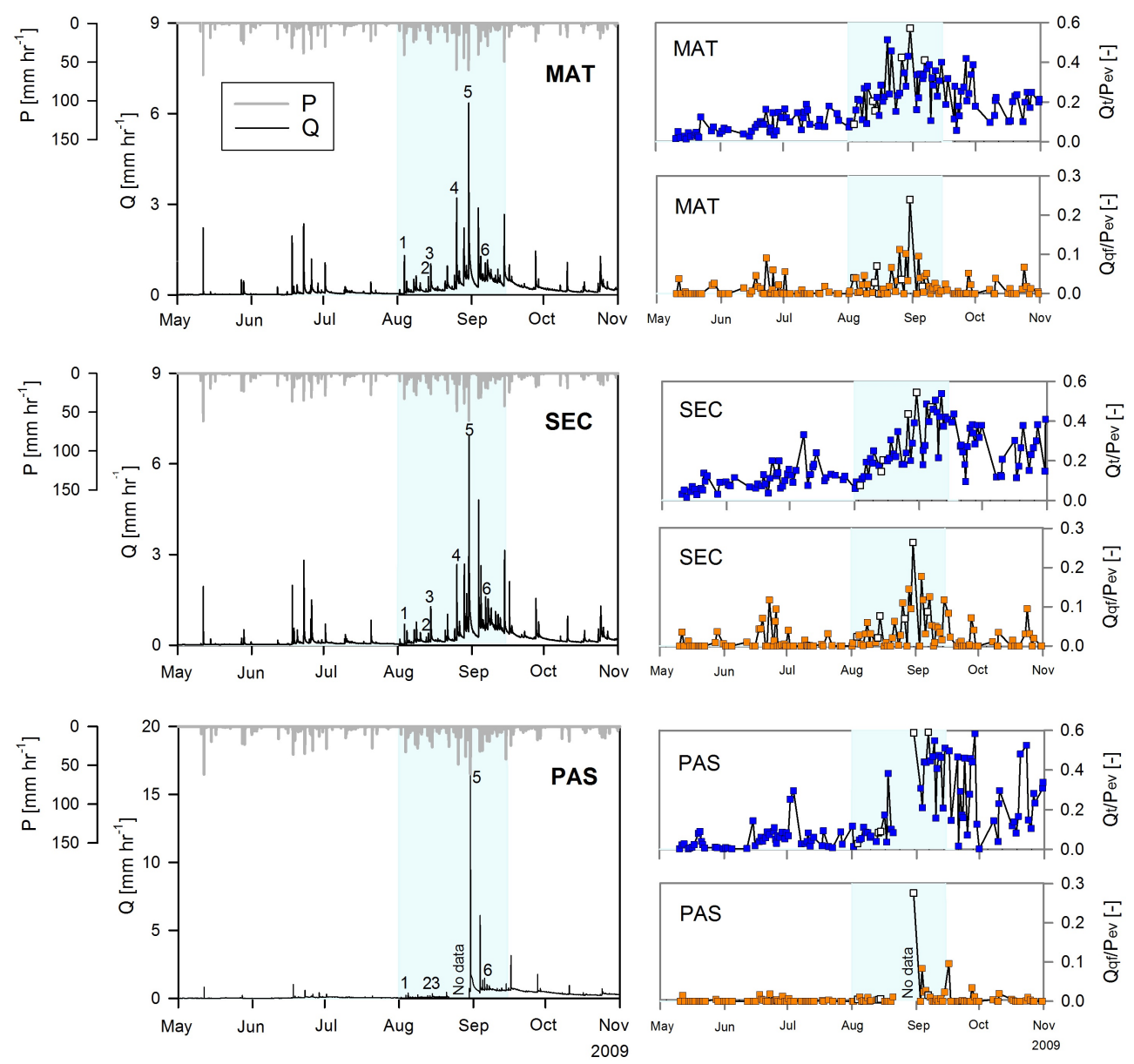

Fig. 3. Hourly depths of rainfall, $P$ (top $y$ axis; grey bars) and streamflow, $Q$ (bottom $y$ axis; black lines), as measured at the three study catchments from 1 May to 31 October, 2009 (left panels). The numbers denote the six rain storms analyzed using the HS techniques. Right panels show the corresponding storm runoff event ratios $\left(Q_{\mathrm{t}} / P_{\mathrm{ev}} ; Q_{\mathrm{qf}} / P_{\mathrm{ev}}\right)$. The white squares show the event ratios of the six storms investigated. The cyan-shaded area indicates the 6-week wetting-up cycle period studied (1 August to 14 September 2009 ).

wetness increased (Table 3). In all three catchments, the increases in the rainfall-runoff ratios were associated with increases in baseflow contributions to total stormflow (from 55 to $92 \%$ in the MAT, 53 to $87 \%$ in the SEC and 50 to $97 \%$ in the PAS).

For all three catchments, the maximum rainfall-runoff event responses were observed during Storm 5, which was the largest and most intense event observed during the study period that occurred when antecedent wetness was high (Table 3). Peak flow discharge in this storm was almost two times higher in the PAS $\left(11.8 \mathrm{~mm} \mathrm{~h}^{-1}\right)$ as compared to the MAT $\left(6.4 \mathrm{~mm} \mathrm{~h}^{-1}\right)$ and SEC $\left(6.9 \mathrm{~mm} \mathrm{~h}^{-1}\right)$.

\subsubsection{End-members signatures $\left({ }^{2} \mathrm{H},{ }^{18} \mathrm{O}, \mathrm{EC}\right)$}

The isotope ratio in bulk rainfall samples of the storms analyzed ranged from -88.7 to $-10.3 \%$ ofor $\delta^{2} \mathrm{H}$ and from -13.2 to $-2.7 \%$ o for $\delta^{18} \mathrm{O}$. Corresponding values of EC ranged from 2.4 to $14.2 \mu \mathrm{S} \mathrm{cm}^{-1}$. Isotope ratios and $\mathrm{EC}$ val- ues in rainfall samples were not statistically different between the sampling locations ( $p=0.421$ for $\delta^{2} \mathrm{H} ; p=0.548$ for $\delta^{18} \mathrm{O}$; and $p=0.269$ for EC). Although the samples of throughfall taken in the MAT and SEC were somewhat enriched in $\delta^{18} \mathrm{O}$ and $\delta^{2} \mathrm{H}(-4.4$ and $-19.5 \%$ on average, respectively) as compared to rainfall ( -5.7 and $-29.8 \%$ on average, respectively), differences were not statistically different ( $p \geq 0.05$ ). In contrast to rainfall, the isotopic variation in stream baseflow was very small (Table 4$)$. The EC concentrations in storm runoff were generally low (range: 11 to $\left.32 \mu \mathrm{S} \mathrm{cm}^{-1}\right)$ and statistically different among sites $(p \leq$ 0.001 ). The isotope ratios in samples of storm runoff from the forests had very similar average and range $(p \geq 0.05)$, but were significantly more depleted $(p \leq 0.001)$ and more variable in the PAS. In all three catchments, soil water was isotopically enriched as compared to stream baseflow (Table 4). In the forests, the EC of soil water was higher compared to stream baseflow, whereas the opposite was observed in most of the storms in the PAS. Figure 4 shows that the 
Table 3. Summary of the rainfall and storm runoff characteristics of the six storms analyzed during the 6-week wetting-up period in the study catchments.

\begin{tabular}{|c|c|c|c|c|c|c|c|c|c|c|c|c|c|c|c|c|c|c|}
\hline & \multicolumn{3}{|c|}{ Storm 1} & \multicolumn{3}{|c|}{ Storm 2} & \multicolumn{3}{|c|}{ Storm 3} & \multicolumn{3}{|c|}{ Storm 4} & \multicolumn{3}{|c|}{ Storm 5} & \multicolumn{3}{|c|}{ Storm 6} \\
\hline Date & \multicolumn{3}{|c|}{3 Aug 2009} & \multicolumn{3}{|c|}{13 Aug 2009} & \multicolumn{3}{|c|}{14 Aug 2009} & \multicolumn{3}{|c|}{26 Aug 2009} & \multicolumn{3}{|c|}{30 Aug 2009} & \multicolumn{3}{|c|}{6 Sep 2009} \\
\hline \multirow{2}{*}{$\begin{array}{l}\text { Rain producing } \\
\text { system }\end{array}$} & \multicolumn{3}{|c|}{ Tropical wave No. 19} & \multicolumn{3}{|c|}{ Convection } & \multicolumn{3}{|c|}{ Convection } & \multicolumn{3}{|c|}{ Convection } & \multicolumn{3}{|c|}{ Tropical wave No. 27} & \multicolumn{3}{|c|}{ Convection } \\
\hline & MAT & SEC & PAS & MAT & SEC & PAS & MAT & SEC & PAS & MAT & SEC & PAS & MAT & SEC & PAS & MAT & SEC & PAS \\
\hline $\begin{array}{l}P_{\mathrm{ev}}, \mathrm{mm} \\
I_{60 \text { mean }}, \mathrm{mm} \mathrm{h}^{-1}\end{array}$ & \multicolumn{2}{|c|}{$\begin{array}{l}35 \\
17\end{array}$} & $\begin{array}{l}30 \\
15 \\
\end{array}$ & \multicolumn{2}{|c|}{$\begin{array}{l}23 \\
12\end{array}$} & $\begin{array}{l}21 \\
11 \\
\end{array}$ & \multicolumn{2}{|c|}{$\begin{array}{l}44 \\
11\end{array}$} & $\begin{array}{l}47 \\
15\end{array}$ & \multicolumn{2}{|c|}{$\begin{array}{c}31 \\
3\end{array}$} & $\begin{array}{l}- \\
- \\
\end{array}$ & \multicolumn{2}{|c|}{$\begin{array}{l}101 \\
25\end{array}$} & $\begin{array}{l}111 \\
28\end{array}$ & \multicolumn{2}{|c|}{$\begin{array}{c}34 \\
8\end{array}$} & $\begin{array}{l}27 \\
8 \\
\end{array}$ \\
\hline $\begin{array}{l}I_{60 \max }, \mathrm{mm} \mathrm{h}^{-1} \\
T_{\mathrm{p}}, \mathrm{h}\end{array}$ & \multicolumn{2}{|c|}{$\begin{array}{c}33 \\
2\end{array}$} & $\begin{array}{l}27 \\
2\end{array}$ & \multicolumn{2}{|c|}{$\begin{array}{c}16 \\
2\end{array}$} & $\begin{array}{l}16 \\
2\end{array}$ & \multicolumn{2}{|c|}{$\begin{array}{c}23 \\
4\end{array}$} & $\begin{array}{l}20 \\
3\end{array}$ & \multicolumn{2}{|c|}{$\begin{array}{c}20 \\
9\end{array}$} & $\begin{array}{l}- \\
- \\
-\end{array}$ & \multicolumn{2}{|c|}{$\begin{array}{c}63 \\
4\end{array}$} & $\begin{array}{l}68 \\
4\end{array}$ & \multicolumn{2}{|c|}{$\begin{array}{c}18 \\
4\end{array}$} & $\begin{array}{l}15 \\
3\end{array}$ \\
\hline$Q_{\mathrm{qf}}, \mathrm{mm}$ & 1.7 & 0.85 & 0.15 & 0.8 & 0.54 & 0.08 & 3.2 & 3.4 & 0.26 & 0.85 & 1.5 & - & 22.8 & 25.8 & 34.5 & 2.6 & 3.2 & 0.42 \\
\hline$Q_{\mathrm{t}}, \mathrm{mm}$ & 3.8 & 2.6 & 0.9 & 4.5 & 3.9 & 1.8 & 10.2 & 8.9 & 4.1 & 10.1 & 8.6 & - & 54.4 & 52.7 & 65.0 & 14.6 & 17.1 & 15.9 \\
\hline $\begin{array}{l}Q_{\mathrm{qf}} / P_{\mathrm{ev}} \\
Q_{\mathrm{t}} / P_{\mathrm{ev}}\end{array}$ & $\begin{array}{l}0.05 \\
0.11\end{array}$ & $\begin{array}{l}0.02 \\
0.07\end{array}$ & $\begin{array}{l}0.00 \\
0.03\end{array}$ & $\begin{array}{l}0.04 \\
0.20\end{array}$ & $\begin{array}{l}0.02 \\
0.16\end{array}$ & $\begin{array}{l}0.00 \\
0.08\end{array}$ & $\begin{array}{l}0.07 \\
0.23\end{array}$ & $\begin{array}{l}0.08 \\
0.20\end{array}$ & $\begin{array}{l}0.01 \\
0.09\end{array}$ & $\begin{array}{l}0.03 \\
0.33\end{array}$ & $\begin{array}{l}0.05 \\
0.27\end{array}$ & $\begin{array}{l}- \\
-\end{array}$ & $\begin{array}{l}0.23 \\
0.54\end{array}$ & $\begin{array}{l}0.26 \\
0.52\end{array}$ & $\begin{array}{l}0.32 \\
0.59\end{array}$ & $\begin{array}{l}0.08 \\
0.43\end{array}$ & $\begin{array}{l}0.10 \\
0.52\end{array}$ & $\begin{array}{l}0.02 \\
0.59\end{array}$ \\
\hline $\mathrm{API}_{7}$, days & \multicolumn{2}{|c|}{9} & 8 & \multicolumn{2}{|c|}{142} & 152 & \multicolumn{2}{|c|}{134} & 113 & & 62 & - & & & 205 & & 84 & 322 \\
\hline $\begin{array}{l}\text { Time lag, min } \\
\text { Time to peak dis- } \\
\text { charge, min }\end{array}$ & $\begin{array}{l}40 \\
70\end{array}$ & $\begin{array}{l}40 \\
70\end{array}$ & $\begin{array}{l}40 \\
60\end{array}$ & $\begin{array}{l}50 \\
80\end{array}$ & $\begin{array}{l}70 \\
80\end{array}$ & $\begin{array}{l}30 \\
30\end{array}$ & $\begin{array}{l}80 \\
100\end{array}$ & $\begin{array}{l}70 \\
90\end{array}$ & $\begin{array}{l}40 \\
40\end{array}$ & $\begin{array}{l}80 \\
120\end{array}$ & $\begin{array}{l}20 \\
40\end{array}$ & $\begin{array}{l}- \\
-\end{array}$ & $\begin{array}{l}40 \\
70\end{array}$ & $\begin{array}{l}20 \\
40\end{array}$ & $\begin{array}{l}20 \\
20\end{array}$ & $\begin{array}{l}70 \\
120\end{array}$ & $\begin{array}{l}40 \\
130\end{array}$ & $\begin{array}{l}20 \\
20\end{array}$ \\
\hline
\end{tabular}

Table 4. Minimum/maximum values, and means $\pm \mathrm{SD}$ of the isotope ratios $\left(\delta^{2} \mathrm{H}\right.$ and $\left.\delta^{18} \mathrm{O}\right)$ and EC concentrations of the different endmembers corresponding to the six storms analyzed using HS techniques.

\begin{tabular}{|c|c|c|c|c|c|c|c|c|c|}
\hline & \multicolumn{3}{|c|}{$\delta^{2} \mathrm{H}, \%$} & \multicolumn{3}{|c|}{$\delta^{18} \mathrm{O}, \%$} & \multicolumn{3}{|c|}{$\mathrm{EC}, \mu \mathrm{S} \mathrm{cm}^{-1}$} \\
\hline & MAT & SEC & PAS & MAT & SEC & PAS & MAT & SEC & PAS \\
\hline Bulk rainfall & $\begin{array}{l}-29.8 \pm 24.4 \\
-76.6 /-10.3\end{array}$ & $\begin{array}{l}-29.8 \pm 24.4 \\
-76.6 /-10.3\end{array}$ & $\begin{array}{l}-38.1 \pm 29.1 \\
-88.7 /-16.1\end{array}$ & $\begin{array}{l}-5.7 \pm 3.1 \\
-11.6 /-2.7\end{array}$ & $\begin{array}{l}-5.7 \pm 3.1 \\
-11.6 /-2.7\end{array}$ & $\begin{array}{l}-6.7 \pm 3.8 \\
-13.1 /-3.4\end{array}$ & $\begin{array}{l}8.9 \pm 3.7 \\
3.4-14.2\end{array}$ & $\begin{array}{l}8.9 \pm 3.7 \\
3.4-14.2\end{array}$ & $\begin{array}{l}5.9 \pm 2.8 \\
2.4-9.7\end{array}$ \\
\hline Rainfall $^{(a)}$ & $\begin{array}{l}-28.8 \pm 21.2 \\
-68.5 /-9.7\end{array}$ & $\begin{array}{l}-28.8 \pm 21.2 \\
-68.5 /-9.7\end{array}$ & $\begin{array}{l}-34.4 \pm 22.5 \\
-71.5 /-12.8\end{array}$ & $\begin{array}{l}-5.5 \pm 2.7 \\
-10.5 /-2.9\end{array}$ & $\begin{array}{l}-5.5 \pm 2.7 \\
-10.5 /-2.9\end{array}$ & $\begin{array}{l}-6.1 \pm 2.8 \\
-10.7 /-3.1\end{array}$ & $\begin{array}{l}6.7 \pm 2.2 \\
3.6-9.5\end{array}$ & $\begin{array}{l}6.7 \pm 2.2 \\
3.6-9.5\end{array}$ & $\begin{array}{l}5.9 \pm 2.3 \\
3.3-8.3\end{array}$ \\
\hline Soil water ${ }^{(b)}$ & $\begin{array}{l}-39.5 \pm 4.9 \\
-42.5 /-32.5\end{array}$ & $\begin{array}{l}-42.2 \pm 7.9 \\
-53.2 /-31.2\end{array}$ & $\begin{array}{l}-47.2 \pm 12.7 \\
-61.4 /-32.3\end{array}$ & $\begin{array}{l}-6.8 \pm 0.7 \\
-7.3 /-5.9\end{array}$ & $\begin{array}{l}-7.1 \pm 1.0 \\
-8.6 /-5.8\end{array}$ & $\begin{array}{l}-7.6 \pm 1.6 \\
-9.6 /-5.7\end{array}$ & $\begin{array}{l}32.5 \pm 4.8 \\
27.5-37.0\end{array}$ & $\begin{array}{l}35.3 \pm 6.0 \\
28.0-44.2\end{array}$ & $\begin{array}{l}20.8 \pm 7.7 \\
8.0-28.0\end{array}$ \\
\hline Storm runoff $^{(c)}$ & $\begin{array}{l}-39.9 \pm 3.6 \\
-46.1 /-29.5\end{array}$ & $\begin{array}{l}-38.1 \pm 4.2 \\
-46.2 /-24.7\end{array}$ & $\begin{array}{l}-46.9 \pm 4.7 \\
-70.6 /-33.6\end{array}$ & $\begin{array}{l}-6.9 \pm 0.5 \\
-7.7 /-5.4\end{array}$ & $\begin{array}{l}-6.7 \pm 0.6 \\
-7-9 /-4.8\end{array}$ & $\begin{array}{l}-7.6 \pm 0.6 \\
-10.7 /-6.1\end{array}$ & $\begin{array}{l}15.8 \pm 3.0 \\
12.6-26.4\end{array}$ & $\begin{array}{l}18.2 \pm 1.0 \\
15.5-22.5\end{array}$ & $\begin{array}{l}24.8 \pm 3.0 \\
11.4-32.3\end{array}$ \\
\hline Baseflow $^{(d)}$ & $\begin{array}{l}-43.2 \pm 0.8 \\
-44.4 /-42.3\end{array}$ & $\begin{array}{l}-41.3 \pm 1.6 \\
-42.9 /-38.4\end{array}$ & $\begin{array}{l}-47.4 \pm 3.1 \\
-49.4 /-41.8\end{array}$ & $\begin{array}{l}-7.4 \pm 0.3 \\
-7.8 /-7.11\end{array}$ & $\begin{array}{l}-7.0 \pm 0.4 \\
-7.5 /-6.4\end{array}$ & $\begin{array}{l}-7.7 \pm 0.3 \\
-7.9 /-7.11\end{array}$ & $\begin{array}{l}14.9 \pm 1.0 \\
13.9-16.4\end{array}$ & $\begin{array}{l}18.9 \pm 0.6 \\
18.3-19.6\end{array}$ & $\begin{array}{l}24.4 \pm 3.0 \\
19.0-26.3\end{array}$ \\
\hline
\end{tabular}

a Average of volume-weighted mean values of rainfall collected with the sequential rain sampler (eight discrete samples of rainfall on average per storm).

b Average value across all locations and depths (six and eleven samples on average per storm in the forests and pasture, respectively).

c Average of the storm runoff water samples collected during rainfall (22 samples on average per storm).

${ }^{\mathrm{d}}$ Average of base flow samples collected within the $2 \mathrm{~h}$ prior to the storm runoff sampling (three samples on average per storm).

samples of rainfall, soil water, baseflow and storm runoff all fall along the local meteoric water line (LMWL), with no evidence of evaporative enrichment of the water isotopes in the three catchments.

\subsubsection{Stormflow sources}

The one-tracer $\left(\delta^{2} \mathrm{H}, \delta^{18} \mathrm{O}\right)$ two-component HS analysis showed a progressive increase of pre-event water contributions to total storm runoff from 35 to $99 \%$ (on average, using both $\delta^{2} \mathrm{H}$ and $\delta^{18} \mathrm{O}$ ) in the MAT and from 26 to $92 \%$ in the SEC as antecedent wetness increased (Table 5). Although in the PAS, pre-event water contributions to storm runoff also increased across the wetting-up cycle (from 62 to $97 \%$ ), there were marked differences with the forests: (1) for the first storm sampled under relatively dry antecedent condi- tions, the PAS generated much lower event water discharges $(38 \%)$ than the MAT (66\%) and SEC (74\%; Fig. 5); and (2) for Storm 5 sampled under very wet antecedent conditions, event water discharges in the pasture $(28 \%)$ were much higher than those generated from the forests $(1$ and $6 \%$ for the MAT and SEC, respectively; Fig. 5).

Interestingly, the highest pre-event water contribution to total stormflow observed in the forests occurred during the largest and most intense rainfall event (Storm 5), whereas in the pasture these occurred during Storms 2 and 6, which were considerably smaller and of much lower intensity compared to Storm 5 (Table 5).

It should be noted that the differences between the preevent fractions obtained with $\delta^{2} \mathrm{H}$ or $\delta^{18} \mathrm{O}$ were very small (4-5\% on average). The uncertainty in the derived pre-event 

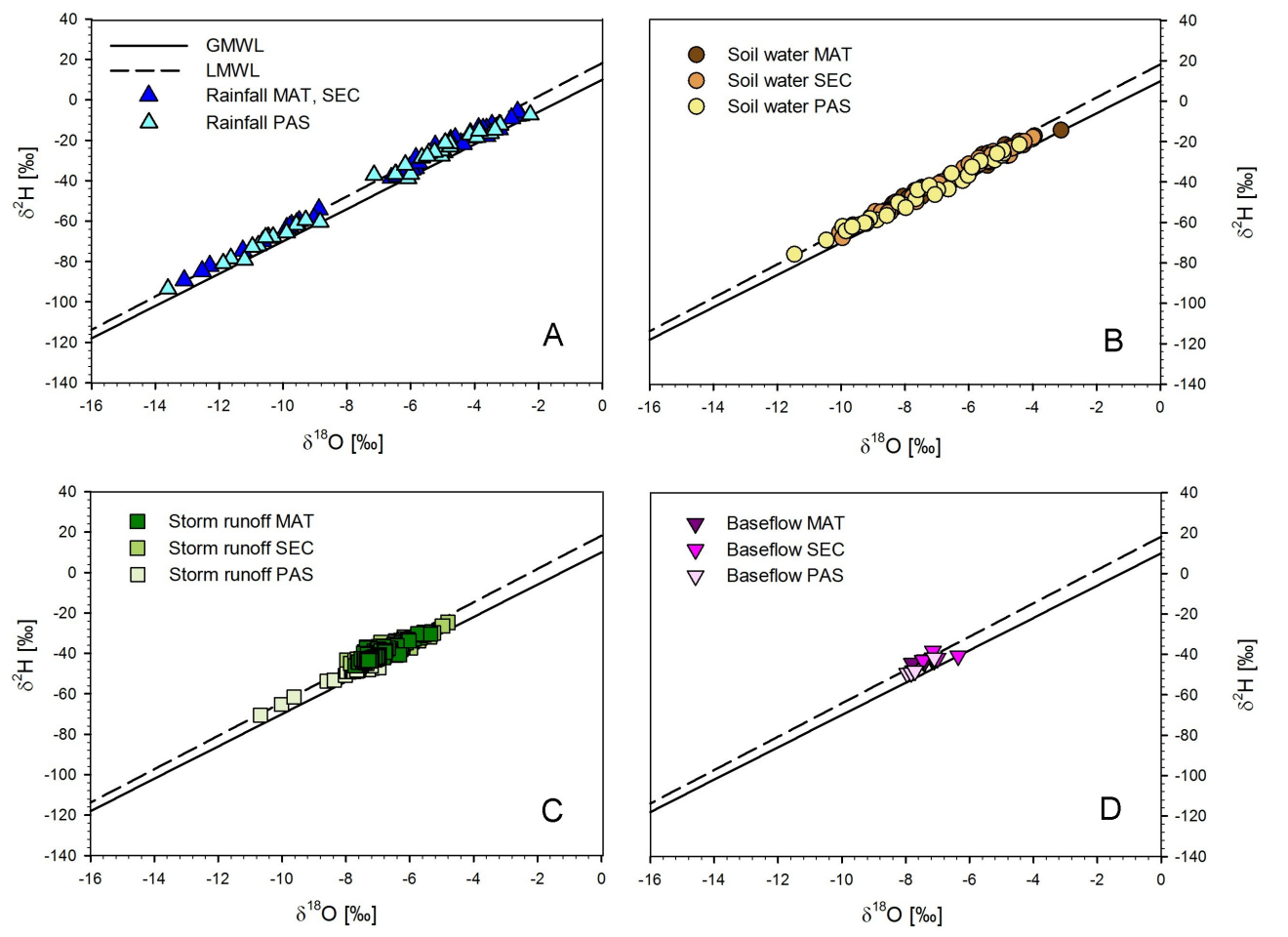

Fig. 4. Water isotope $\left(\delta^{2} \mathrm{H}\right.$ and $\left.\delta^{18} \mathrm{O}\right)$ signatures of (a) rainfall; (b) soil water (all soil depths); (c) storm runoff and (d) baseflow for each of the three study catchments. The local meteoric water line (LMWL; dashed line) is based on the 2008-2010 precipitation data and reads: $\delta^{2} \mathrm{H}$ $=8.25 \cdot \delta^{18} \mathrm{O}+18.20$ (Goldsmith et al., 2012); the solid line represents the global meteoric water line $(\mathrm{GMWL}): \delta^{2} \mathrm{H}=8 \cdot \delta^{18} \mathrm{O}+10$.

water fractions (Sect. 2.4.4) for $\delta^{2} \mathrm{H}$ was, on average, 9,10 and $7 \%$ in the MAT, SEC and PAS, respectively, and 16, 20 and $20 \%$ for $\delta^{18} \mathrm{O}$, respectively.

Two-tracer $\left(\delta^{2} \mathrm{H}, \delta^{18} \mathrm{O}\right.$ and EC) three-component HS analysis showed that at relatively dry antecedent wetness conditions, runoff during Storm 1 in the MAT and SEC was largely generated by event water sources (74 and $97 \%$, respectively; Fig. 6). However, as antecedent wetness increased (Storms 2, 3 and 4), soil and groundwater contributions to storm runoff increased, and groundwater became rapidly the largest component of the pre-event water fraction in both forest catchments (Table 5). When antecedent wetness was at the highest (Storms 5 and 6), stormflow in the MAT and SEC was completely pre-event water dominated and consisted almost entirely of groundwater (82 and $86 \%$ on average for Storms 5 and 6, respectively). Surprisingly, in both forests, groundwater contributions to total stormflow were highest during Storm 5 (90 and $88 \%$ for the MAT and SEC, respectively; Table 5, Fig. 6), which was the largest and most intense storm of the study period.

For most of the storms, groundwater sources also dominated the storm runoff in the PAS (Table 6), except for Storm 5 during which the pre-event water was calculated to be, on average, 22 and $39 \%$ of soil and groundwater, respectively (Fig. 6).
In agreement with the one-tracer two-component HS analysis, the most pronounced differences found between the stormflow response of the forests and pasture catchments occurred under contrasting antecedent wetness conditions, and in the largest and most intense event sampled. At the beginning of the wetting-up period (Storm 1), event water sources in runoff were 5-fold and 7-fold higher in the MAT (74\%) and SEC (97\%) as compared to the PAS (15\%). During the largest rainfall event occurring at the end of the wetting-up cycle (Storm 5), the event water contribution in storm runoff from the PAS (40\%) was 6- to 20-fold higher compared to the SEC (7\%) and MAT (2\%), respectively (Table 5; Fig. 6).

Regression analysis showed that the event water fraction in stormflow from the pasture was strongly, positively correlated with storm characteristics, such as total rainfall, $P_{\mathrm{ev}}\left(r^{2}=0.91\right)$ and the maximum hourly rainfall intensity, $I_{60 \max }\left(r^{2}=0.94\right)$, whereas no correlation was found with $\mathrm{API}_{7}\left(r^{2}=0.01\right)$. In contrast, event water contributions to runoff from the forests showed a strong, inverse correlation with $\mathrm{API}_{7}\left(r^{2}=0.65\right.$ and 0.63 for the MAT and SEC, respectively), yet very poor relationships with $P_{\mathrm{ev}}$ $\left(r^{2}=0.12\right.$ and 0.10 , respectively) and no correlation with $I_{60 \max }\left(r^{2} \leq 0.002\right)$. 
Storm 1
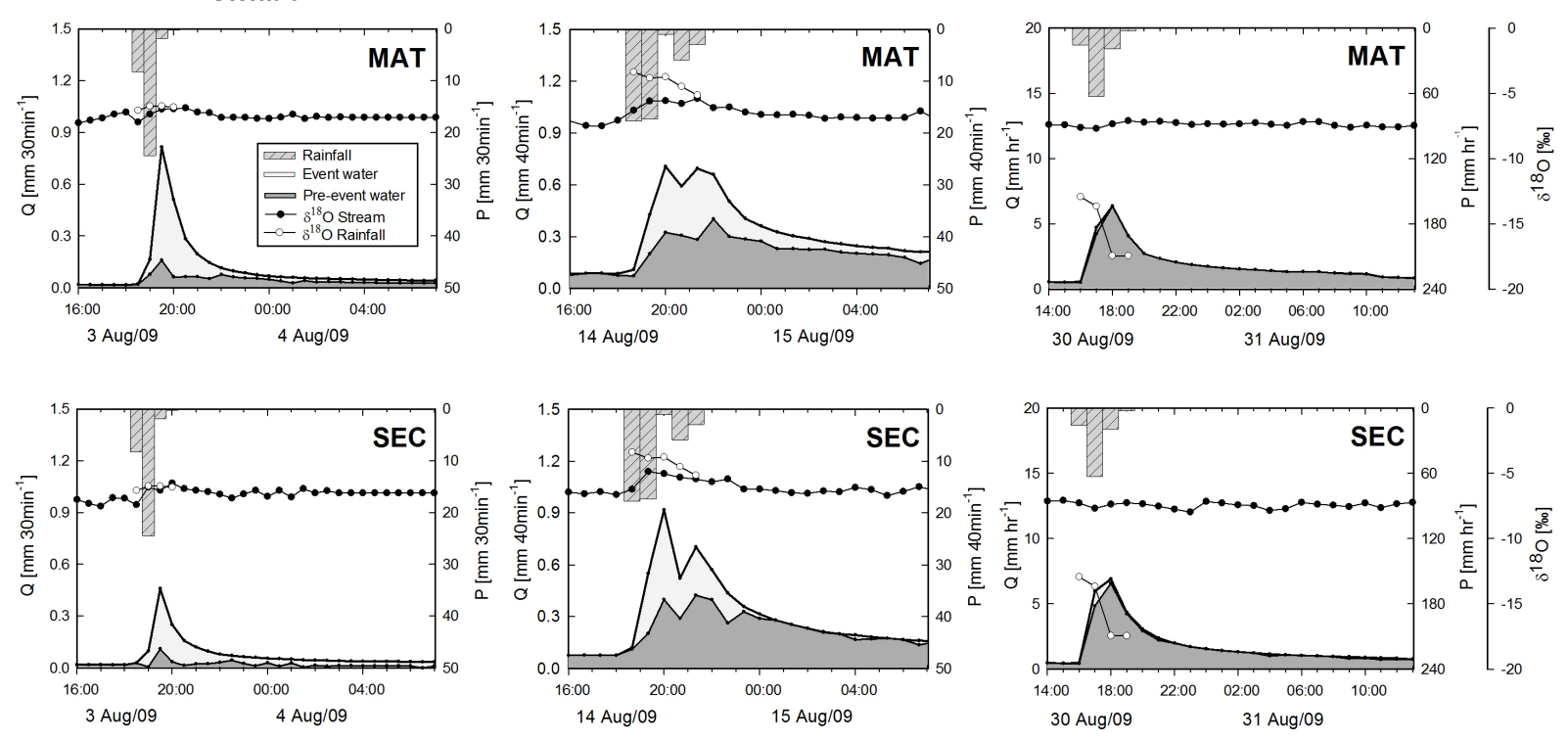

Storm 5
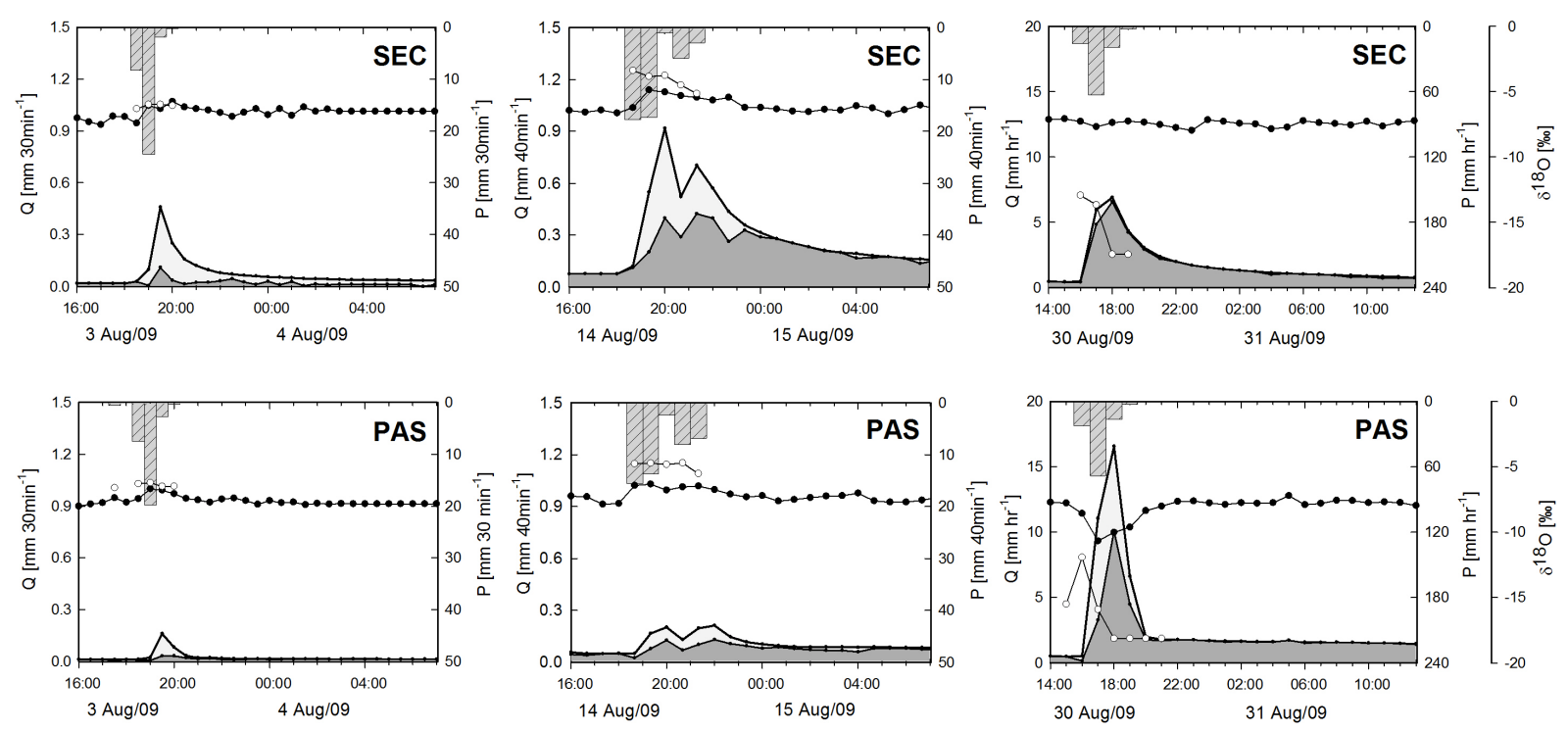

Fig. 5. The partitioning of storm runoff into its pre-event and event water sources using one-tracer $\left(\delta^{18} \mathrm{O}\right)$ two-component HS analysis for Storms 1, 3 and 5 sampled during the 6-week wetting-up cycle period for each of the three study catchments. Note that the rainfall $(P)$ and streamflow $(Q)$ data for Storm 5 are plotted on different scales according to Storm 1 and 3 for a better representation.

Table 5. Pre-event water contributions to storm runoff as obtained using one-tracer $\left(\delta^{2} \mathrm{H}, \delta^{18} \mathrm{O}\right)$ two-component $\mathrm{HS}$, and corresponding storm runoff contributing sources as derived from two-tracer $\left(\delta^{2} \mathrm{H}, \delta^{18} \mathrm{O}\right.$ and EC) three-component HS analyses for each of the storms analyzed in the three study catchments.

\begin{tabular}{|c|c|c|c|c|c|c|c|c|c|c|c|c|c|c|c|c|c|c|}
\hline & \multicolumn{3}{|c|}{ Storm 1} & \multicolumn{3}{|c|}{ Storm 2} & \multicolumn{3}{|c|}{ Storm 3} & \multicolumn{3}{|c|}{ Storm 4} & \multicolumn{3}{|c|}{ Storm 5} & \multicolumn{3}{|c|}{ Storm 6} \\
\hline & MAT & SEC & PAS & MAT & SEC & PAS | & MAT & SEC & PAS & MAT & SEC & PAS & MAT & SEC & PAS & MAT & SEC & PAS \\
\hline $\begin{array}{l}\text { Pre-event water } \\
\delta^{2} \mathrm{H}, \% \\
\delta^{18} \mathrm{O}, \%\end{array}$ & $\begin{array}{l}31 \\
38\end{array}$ & $-\overline{26}$ & $\begin{array}{l}64 \\
60\end{array}$ & $\begin{array}{l}79 \\
81\end{array}$ & $\begin{array}{l}79 \\
79\end{array}$ & $\begin{array}{l}91 \\
93\end{array}$ & $\begin{array}{l}72 \\
66\end{array}$ & $\begin{array}{l}63 \\
73\end{array}$ & $\begin{array}{l}75 \\
72\end{array}$ & $\begin{array}{l}88 \\
93\end{array}$ & $\begin{array}{l}84 \\
81\end{array}$ & $\begin{array}{l}- \\
-\end{array}$ & $\begin{array}{l}99 \\
99\end{array}$ & $\begin{array}{l}93 \\
95\end{array}$ & $\begin{array}{l}71 \\
74\end{array}$ & $\begin{array}{l}92 \\
88\end{array}$ & $\begin{array}{l}92 \\
84\end{array}$ & $\begin{array}{l}96 \\
97\end{array}$ \\
\hline $\begin{array}{l}\text { Stormflow } \\
\text { sources } \\
\delta^{2} \mathrm{H} \text { and EC }\end{array}$ & & & & & & & & & & & & & & & & & & \\
\hline Rainfall, \% & 74 & - & 15 & 19 & 22 & 1 & 25 & 21 & 11 & 13 & 22 & - & 1 & 3 & 39 & 8 & 11 & 1 \\
\hline Soil water, \% & 18 & - & 0 & 26 & 8 & 0 & 25 & 0 & 0 & 2 & 13 & - & 9 & 1 & 23 & 5 & 0 & 0 \\
\hline $\begin{array}{l}\text { Groundwater, \% } \\
\delta^{18} \mathrm{O} \text { and EC }\end{array}$ & 8 & - & 85 & 55 & 70 & 99 & 50 & 79 & 89 & 85 & 65 & - & 90 & 96 & 38 & 87 & 88 & 99 \\
\hline Rainfall, \% & 73 & 97 & 15 & 17 & 22 & 1 & 29 & 24 & 14 & 8 & 24 & - & 2 & 10 & 40 & 14 & 15 & 0 \\
\hline Soil water, \% & 21 & 2 & 0 & 25 & 8 & 7 & 26 & 0 & 0 & 5 & 14 & - & 9 & 10 & 20 & 10 & 2 & 0 \\
\hline Groundwater, \% & 6 & 1 & 85 & 58 & 70 & 93 & 45 & 76 & 86 & 86 & 62 & - & 89 & 80 & 40 & 76 & 83 & 100 \\
\hline
\end{tabular}



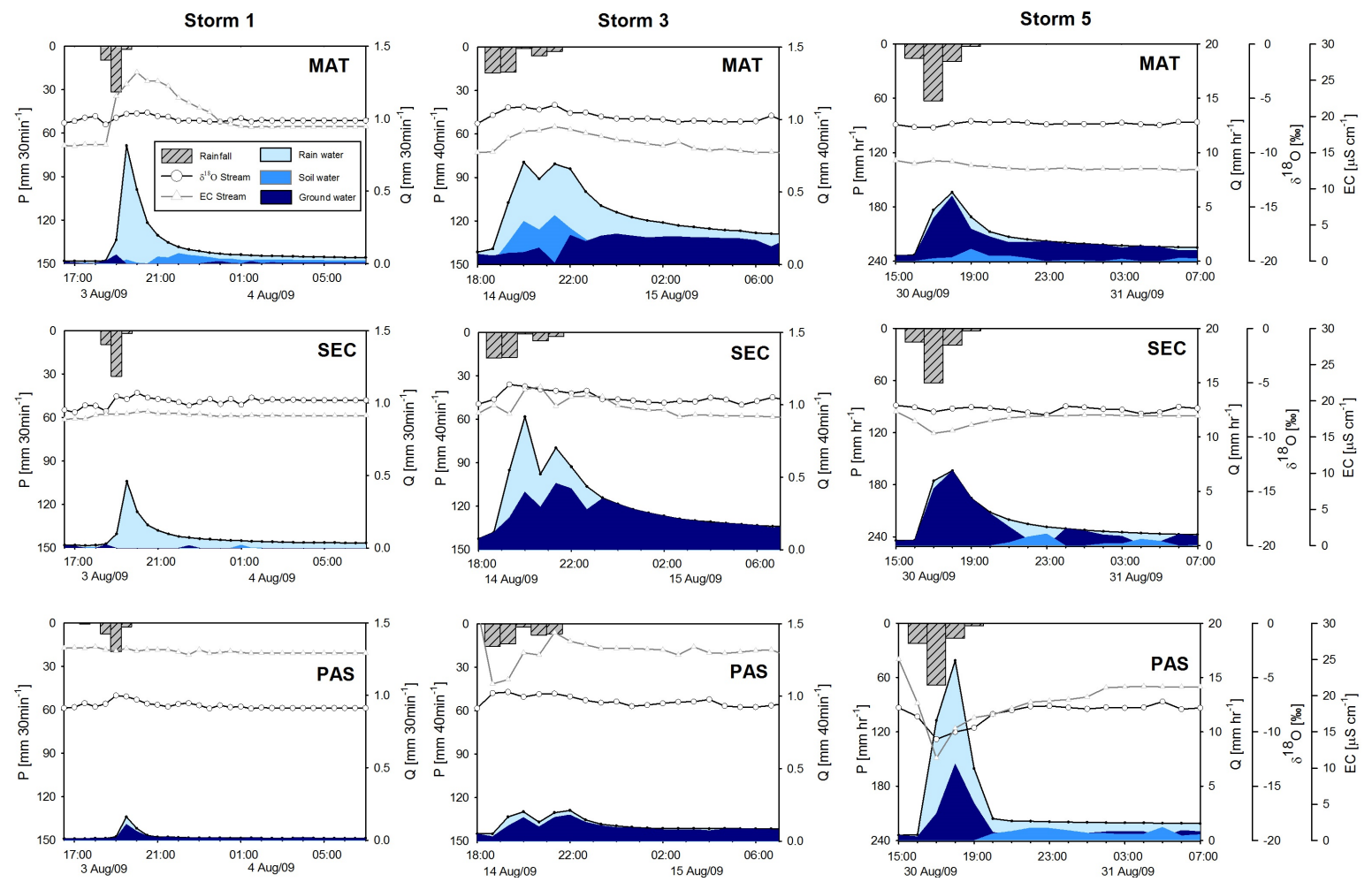

Fig. 6. Storm runoff contributing sources using two-tracer $\left(\delta^{18} \mathrm{O}\right.$ and EC) three-component HS analysis for Storms 1,3 and 5 sampled during the 6-week wetting-up cycle period for each of the three study catchments. Note that the rainfall $(P)$ and streamflow $(Q)$ data for Storm 5 are plotted on different scales according to Storm 1 and 3 for a better representation.

\subsubsection{Stream discharge-EC relations}

Across the wetting-up cycle, the MAT showed consistently positive discharge-EC relationships, i.e. increasing EC with increasing storm discharge $\left(r^{2}=0.72\right.$ on average). In addition, a combination of discharge-EC hysteretic patterns was observed: an anticlockwise loop from Storm 1 to 3 that shifted to a clockwise loop from Storm 4 onwards (Fig. 7). In contrast, anticlockwise loops dominated in the SEC and PAS (Fig. 7). Furthermore, both the SEC and PAS catchments showed a positive discharge-EC relationship from Storm 1 to 3 ( $r^{2}=0.29$ and 0.26 on average, respectively), meanwhile inverse relationships (i.e. decreasing EC with increasing storm discharge) characterized Storms 4 to 6 in the SEC $\left(r^{2}=0.36\right.$ on average $)$, and Storms 5 and 6 in the PAS $\left(r^{2}=0.32\right)$.

\section{Discussion}

Our process-based hydrological work showed very similar catchment annual and seasonal streamflow regimes, and storm runoff event responses for the $20 \mathrm{yr}$-old regenerating forest and the old-growth forest. For the $2 \mathrm{yr}$ study period, the pasture showed higher annual streamflows in comparison to the forested catchments, mostly through an increase in baseflow. Major differences in storm runoff characteristics, flow sources and pathways between the two forests and the pasture catchments were only expressed under conditions of high rainfall intensity and high antecedent wetness. For most events and at all three catchments, vertical soil water percolation through the permeable volcanic soils and underlying substrate promoted storm runoff responses that were dominated by subsurface flow processes.

\subsection{Similarities in runoff generation between the mature and secondary cloud forest}

Annual runoff ratios $(Q / P)$ for the two hydrological years were on average $5 \%$ higher $(145 \mathrm{~mm})$ in the regenerating forest as compared to the mature forest catchment. Changes in streamflow after cloud forest disturbance or conversion to other land covers reflect concurrent changes in evapotranspiration (ET) and cloud water interception (Bruijnzeel et al., 2011). Previous work at this site showed that inputs of cloud water interception by the mature and secondary cloud forests are very low ( $\leq 2 \%$ of annual $P$; Holwerda et al., 2010), so that the observed differences in streamflow most likely reflect differences in ET. Muñoz-Villers et al. (2012) showed that while annual transpiration totals of both forests were nearly equal $(\sim 790 \mathrm{~mm})$, rainfall interception loss by the secondary forest $\left(\sim 280 \mathrm{~mm} \mathrm{yr}^{-1}, 8 \%\right.$ of $\left.P\right)$ was about half that 

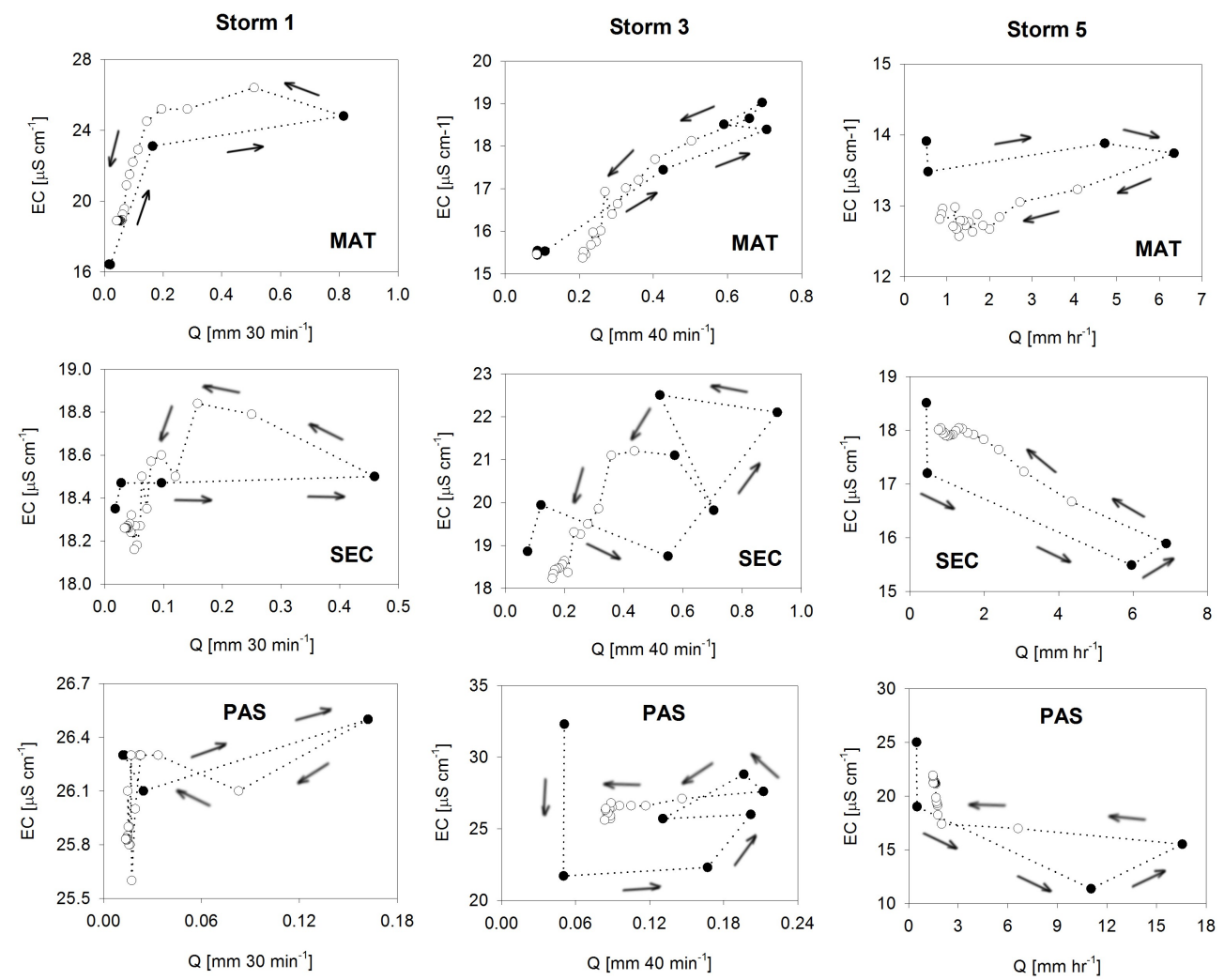

Fig. 7. Temporal dynamic in the relationship between storm runoff and electrical conductivity for Storms 1,3 and 5 sampled during the 6-week wetting-up cycle period for each land cover catchment studied. The solid and open circles indicate the rising and falling limb of the stream hydrograph, respectively. The arrows indicate the direction of the hysteresis pattern (clockwise or anticlockwise loops).

by the mature forest $\left(\sim 560 \mathrm{~mm} \mathrm{yr}^{-1}, 16 \%\right.$ of $P$; Holwerda et al., 2010). The smaller loss observed for the secondary forest was attributed to a lower canopy water storage capacity, related in turn to a lower leaf area index and lower epiphyte biomass (Holwerda et al., 2010). Hence, the small difference in total annual streamflow found between the forests most likely reflects a difference in interception loss (MuñozVillers et al., 2012).

The hydrological similarities between the forests were also reflected in their storm runoff generation mechanisms. From our storm hydrograph separation analysis carried out during the 6-week wetting-up period, we observed that both forest catchments showed remarkably similar event runoff ratios that, along with baseflow contributions to stormflow, progressively increased as the wetting-up cycle advanced. We also observed almost identical contributions of pre-event water sources to total stormflow across the sequence of rain events sampled in the regenerating forest and mature forest. As antecedent wetness increased, the role of subsurface water pathways increased in importance and groundwater sources became ultimately the largest component of storm runoff generation (as also shown by Muñoz-Villers and McDonnell, 2012). These findings are consistent with hydrometric results obtained from a steep forested headwater catch- ment on volcanic substrate at Hitachi Ohta Experimental Watershed, Japan, where Sidle et al. (2000) and Sidle (2006) observed that hillslope subsurface flow increased as antecedent wetness increased.

Although sources and composition of stormflow were seemingly very similar between the two forests across the wetting-up period, the stream discharge-EC relationships suggest that there were subtle mechanistic differences in the storm runoff generation. The mature forest showed a consistent positive relationship between storm event runoff and stream conductivity. Conversely, the secondary forest showed a shift from a positive to an inverse relationship from Storm 5 onwards. This change in the storm discharge-EC pattern might appears to suggest a small increase in the contribution of the shallow lateral sources to storm runoff in the secondary forest, and might have been triggered by the high rainfall intensity occurring under conditions of very high antecedent wetness. We speculate that such change is due more to catchment subsurface characteristics than to forest age or stand characteristics. More work is needed to separate the pedo-geological and vegetation influences.

Runoff generation processes at catchment scale in secondary tropical forest are virtually undocumented (Bruijnzeel, 2004), despite it is becoming the dominant land 
vegetation cover in humid tropical regions (Giambelluca, 2002). However, some work has been carried out at the plot scale to investigate the effects of forest regeneration on soil hydrologic properties. For example, the work of Hassler et al. (2011) in central Panama and Zimmermann et al. (2010) in Rondonia, Brazil both showed that soil saturated hydraulic conductivities can be recovered to pre-disturbance conditions during forest regeneration from pasture, but this process may take more than $8 \mathrm{yr}$.

Our findings suggest that $20 \mathrm{yr}$ of natural regeneration after forest disturbance may be sufficient to largely restore the original catchment hydrology of this tropical forest ecosystem. Rates of forest regrowth, and with it the rate of hydrological recovery, depend largely on the duration and management intensity of the land use prior to regeneration and the associated degree of soil degradation (Ziegler et al., 2004; Zimmermann et al., 2006). For the secondary forest under investigation, soil conditions prior to regeneration are unknown. Hence, it remains uncertain whether the full $20 \mathrm{yr}$ recovery period was needed to restore hydrological behavior or to what extent this was achieved before the present observations started. At any rate, the present results highlight the importance of protecting and promoting naturally regenerating forest to restore hydrological processes of ecosystems. This work also showed that despite the high ET of the forests, the high rainfall amounts prevailing in the wet season along with the high water percolation rates and high water storage potentials of this forest ecosystem promote very important hydrological services to downstream regions, such as dry season base flow sustenance and modulation of rainfall extremes.

\subsection{Effects of forest conversion to pasture on runoff response}

The annual runoff ratio in the pasture was on average $12 \%$ $(286 \mathrm{~mm})$ and $9 \%(145 \mathrm{~mm})$ higher than those observed in the mature forest and regenerating forest catchments, respectively. Again, the increase in streamflow amounts following cloud forest conversion to pasture in this region mostly likely reflects changes in ET. Previous experimental data from this site (Muñoz-Villers et al., 2012) showed that measured annual ET (transpiration plus rainfall interception loss) in the mature and secondary cloud forests were 1350 and $1065 \mathrm{~mm}$, respectively. While no direct measurements of transpiration and rainfall interception for the pasture are available, a FAO Penman-Monteith reference ET calculated for the pasture site would suggest an annual ET of $855 \mathrm{~mm}$ (Muñoz-Villers et al., 2012). Furthermore, the fact that the grass was very short (Sect. 2.1), and thus must have had a low water storage capacity suggests that the interception loss by the pasture was very small compared to the forests (cf. Gash and Shuttleworth, 1991). Finally, a lower ET of the pasture as compared to the forests is consistent with the increase in streamflow observed in the form of baseflow.
Our $12 \%(286 \mathrm{~mm})$ annual streamflow increment observed for the pasture catchment compares somewhat lower with the $17 \%$ ( $377 \mathrm{~mm}$ on average) increment observed by Germer et al. (2010) for two adjacent zero-order stream microcatchments covered with undisturbed open tropical rainforest and pasture on Ultisols in Rondonia, northwestern Brazil.

Overall, our findings fall within the range of expected increases in annual flows after converting forest to pasture in tropical areas (150-300 $\mathrm{mm} \mathrm{yr}^{-1}$, depending on rainfall; Fritsch, 1993; Jipp et al., 1998), where the results from the different regions seem to be mostly dependent on the expected difference in ET (mainly evaporation) between the former and new vegetation cover (Bruijnzeel, 2004, 2005).

Flow duration curves showed the greatest variability in hydrological regime in the pasture, with higher discharges at high flows in the rainy season and lower discharges at low flows during the dry period. Further, our event-based analysis showed rainfall-runoff time responses that were generally shorter as compared to the forests. Likewise, the mean and variance of peak flow in the pasture were higher, notably at high antecedent wetness. The lower rainfall interception of the pasture and its reduced surface soil hydraulic conductivities due to compaction by cattle grazing (Marín-Castro, 2010) likely explains its greater responsiveness to rainfall during the wet season. Several authors have discussed the impacts of forest conversion to pasture on ET (Bruijnzeel, 2004; Jipp et al., 1998) and soil hydraulic properties (Tobón et al., 2010; Ziegler et al., 2004; Zimmermann et al., 2006) in the tropics. Both effects combined can modify the frequency, timing and magnitude of catchment stormflow responses (Chaves et al., 2008; Germer et al., 2009; Roa-García et al., 2011) and runoff generation mechanisms, with a shift from subsurface to surface or near-surface flow pathways (Chaves et al., 2008; Molina et al., 2007).

The baseflow in the pasture at the end of the dry season (March-April) was about 35 and $70 \%$ lower compared to the mature and secondary forest, respectively. A possible explanation for this is a lower recharge of subsurface water storages during the rainy season due to the lower rainfall infiltration capacity of the soil in the pasture. Nevertheless, we cannot rule out a topographic control on these differences in dry season flows. In this regard, Sayama et al. (2011) showed for permeable bedrock substrates in California that catchments with steep gradients tend to store more water than those characterized by gentle slopes, and can therefore sustain dry season flows for longer periods. If so, the fact that forest catchments have steeper slopes and deeper soil profiles as compared to the pasture might be an alternative explanation for their higher baseflows during the dry season.

As it was also shown for the forests, our storm hydrograph separation analysis in the pasture demonstrated progressive increases of rainfall-runoff event ratios $\left(Q_{\mathrm{t}} / P_{\mathrm{ev}}\right)$ across the wetting-up cycle, with stormflow compositions that were entirely dominated by pre-event water sources. Although 
groundwater discharge was also the main source of the subsurface stormflow in the pasture, it appeared to be delivered from a shallower subsurface compartment as compared to the forests. This is supported by the more depleted values and greater variation observed of the isotopic composition of the storm runoff (Table 4; Fig. 4).

It is interesting that despite the one to two orders of magnitude lower surface soil hydraulic conductivity in the pasture as compared to the forests (Table 1), storm runoff in the pasture was also dominated by groundwater sources. A likely explanation for this is that for most of our monitored storms, the average rainfall infiltration rate of the soil was still higher than the average rainfall intensity. In addition, the lower slope gradients of the pasture as compared to the forests could have played a role. Nevertheless, the high correlation found between the event water contributions and rainfall characteristics (amount and intensity) suggests that overland flow did occur in the pasture in response to large storms of high intensity (see also below).

Our findings contrast with those obtained by Chaves et al. (2008) and Germer et al. (2010) for undisturbed rainforest and pasture catchments (0.7-1.4 ha) in Rondonia, Brazil. For a series of storms sampled in the wet season, Chaves et al. (2008) found that event water contributions accounted for 79 and $67 \%$ of the total stormflow in the early, and 51 and $57 \%$ in the late wet season for the forest and pasture, respectively. These results were mainly attributed to the strong decrease of hydraulic conductivity with depth that characterizes the soils of their study area, favoring infiltrating water to be routed via surface and near-surface pathways, so that saturation-excess overland flow was the dominant stormflow generation process in both land covers. In addition, the Brazilian catchments were much smaller compared to our study catchments, which might also in part explain the higher event water contributions in these catchments (c.f. Brown et al., 1999).

Comparing our results for the forests with those for the pasture across the sequence of storms sampled, there were two rain events that occurred under contrasting antecedent wetness for which clear differences in catchment response and runoff generation mechanisms were observed. Firstly, in the first storm sampled under dry antecedent conditions, the forests had much higher event water contributions compared to the pasture. A possible explanation for this might be a (temporal) difference in soil hydrophobicity among the land cover types. Although no data on soil water repellency in the investigated catchments are available, studies on Andisols in southern Chile have demonstrated that this property is strongest and more persistent in forested soils with high organic carbon and nutrient contents in the upper horizons (Ellis et al., 2003). Campos Cascaredo (2010) showed that our mature forest site holds three times higher surface soil organic carbon (28\%) and inorganic nitrogen $(2 \%)$ concentrations compared to the grasslands in this region (10 and $0.8 \%$, respectively). The high nutrient contents of the forests could influence surface soil hydraulic conductivities, and ultimately contribute to produce some overland flow and/or pseudo overland flow (McDonnell et al., 1991a, b), resulting in the initial high event water response. Secondly, for the largest event of our study period (Storm 5), with a return period of about $2 \mathrm{yr}$ (F. Holwerda, unpublished data), that occurred under wet antecedent conditions, the pasture showed about seven times more event water contribution to stormflow $(28-40 \%)$ as compared to the forests $(1-10 \%)$. We attribute this difference to a much lower surface soil infiltration capacity of the pasture and, to a lesser extent, a much lower rainfall interception loss as compared to the forests. Where the forests were able to mitigate the impact of this large and intense storm, despite the high antecedent wetness conditions, rainfall rates probably exceeded surface soil infiltration capacities in the pasture, promoting overland flow and resulting in the higher event water fraction as compared to the forests.

\section{Conclusions}

We found very similar annual and seasonal streamflow regimes, and storm runoff event responses in the mature and secondary forest catchments. Conversely, the pasture catchment showed $10 \%$ higher mean annual streamflow, which most likely reflects a lower rainfall interception. However, at the end of the dry season, baseflow was lowest in the pasture, possibly due to a lower soil infiltration capacity and thus reduced recharge of subsurface water storages. A smaller catchment water storage capacity associated to lower slope gradients in the pasture may also have played a role.

During the 6-week wetting-up cycle, rainfall-runoff event ratios increased at all three catchments (from 7 to $55 \%$ on average). As antecedent wetness increased, pre-event water contributions to total storm runoff also increased from 35 to $99 \%$ in the mature forest, 26 to $92 \%$ in the secondary forest and 64 to $97 \%$ in the pasture. Our results also suggest that in all three catchments and for most of the storms, the permeability of the volcanic soils and substrate led to vertical rainfall percolation and recharge of deeper layers, promoting stormflow responses that were dominated by groundwater from within the hillslope. However, for the largest and most intense storm sampled at high antecedent wetness conditions, the much higher event water contribution in the pasture (28-40\% versus $1-10 \%$ in the forests) suggests that for this storm the rainfall infiltration capacity of the soil in the pasture was exceeded, causing overland flow to occur. The latter result shows that despite the high permeability of the volcanic soils in this region, forest conversion to pasture might cause important shifts in runoff generation processes, sources and pathways during large and high intensity storms. On the other hand, our results also showed the importance of protecting naturally regenerating forest to restore hydrological processes in this TMCF environment, which ultimately 
promote crucial hydrological services to society, i.e. dry season base flow sustenance and modulation of rainfall-runoff responses to high intensity storms in the wet season.

Acknowledgements. We thank the Municipality of Coatepec (Veracruz, Mexico) and the residents of Loma Alta and Tierra Grande for permitting us to work on their land. We would also like to thank Friso Holwerda for providing the rainfall data and for his valuable comments on the manuscript, and Daniel Geissert for sharing the soil physical data of the pasture catchment. Tina Garland and Caroline Patrick are thanked for their assistance in analyzing the isotope samples, and Adán Hernández and Sergio Cruz are thanked for their great help in the field. Finally, we appreciate the valuable comments of three anonymous reviewers. This research was founded by a US National Science Foundation (NSF/DEB 0746179) grant to H. Asbjornsen, T. E. Dawson and J. J. McDonnell, and by Mexico-CONACyT (Repatriación Program, No. 170890) grant to L. E. Muñoz-Villers.

Edited by: T. J. Troy

\section{References}

Arnold, J. G. and Allen, P. M.: Automated methods for estimating baseflow and ground water recharge from streamflow records, J. Am. Water Resour. Ass., 35, 411-424, 1999.

Báez, A. P., Padilla, H., Cervantes, J., Pereyra, D., and Belmont, R.: Rainwater chemistry at the eastern flanks of the Sierra Madre Oriental, Veracruz, Mexico, J. Geophys. Res.-Atmos., 102, 23329-23336, 1997.

Baker, D. B., Richards, R. P., Timothy, T., Loftus, T. T., and Kramer, J.W.: A new flashiness index: characteristics and applications to Midwestern rivers and streams, J. Am. Water Resour. Assess., 40, 503-522, 2004.

Bosch, J. M. and Hewlett, J. D.: A review of catchment experiments to determine the effect of vegetation changes on water yield and evapotranspiration, J. Hydrol., 55, 3-23, 1982.

Brown, A. E., Zhang, L., McMahon, T. A., Western, A. W., and Vertessy, R. A.: A review of paired catchment studies for determining changes in water yield resulting from alterations in vegetation, J. Hydrol., 310, 28-61, 2005.

Brown, V. A., McDonnell, J. J., Burns, D. A., and Kendall, C.: The role of event water, a rapid shallow flow component, and catchment size in summer stormflow, J. Hydrol., 217, 171-190, 1999.

Bruijnzeel, L. A.: Hydrology of Moist Tropical Forest and Effects of Conversion: A State of Knowledge Review. UNESCO, Paris, and Vrije Universiteit Amsterdam, The Netherlands, 226 pp., 1990.

Bruijnzeel, L. A.: Hydrological functions of tropical forests: not seeing the soil for the trees?, Agr. Ecosyst. Environ., 104, 185228, 2004.

Bruijnzeel, L. A.: Tropical montane cloud forest: a unique hydrological case, in: Forests, Water and People in the Humid Tropics, edited by: Bonell, M. and Bruijnzeel, L. A., Cambridge Univ. Press, Cambridge, UK, 462-483, 2005.

Bruijnzeel, L. A., Mulligan, M., and Scatena, F. N.: Hydrometeorology of tropical montane cloud forests: Emerging patterns, Hydrol. Process., 25, 465-498, 2011.
Calder, I. R. and Kidd, C. H. R.: Note on the dynamic calibration of tipping-bucket gauges, J. Hydrol., 39, 383-386, 1978.

Campos Cascaredo, A.: Response of soil inorganic nitrogen to land use and topographic position in the Cofre de Perote Volcano (Mexico), Environ. Manage., 46, 213-224, 2010.

Cayuela, L., Golicher, D. J., and Rey-Benayas, J. M.: The extent, distribution, and fragmentation of vanishing montane cloud forest in the Highlands of Chiapas, Mexico, Biotropica, 38, 544554, 2006.

Challenger, A.: Utilización y Conservación de los Ecosistemas Terrestres de México, Pasado, Presente y Futuro. CONABIO/UNAM/Agrupación Sierra Madre, Mexico City, 1998.

Chapman, T.: A comparison of algorithms for stream flow recession and baseflow separation, Hydrol. Process., 13, 701-714, 1999.

Chaves, J., Neill, C., Germer, S., Gouveia Neto, S., Krusche, A., and Elsenbeer, H.: Land management impacts on runoff sources in small Amazon watersheds, Hydrol. Process., 22, 1766-1775, 2008.

Chhabra A., Geist, H., Houghton, R. A., Haberl, H., Braimoh, A. K., Vlek, P., Patz, J., Xu, J. C., Ramankutty, N., Coomes, O., and Lambin, E. F.: Multiple impacts of land use/cover change, in: Land-use and Land-cover Change: Local Processes and Global Impacts, Lambin, E. F. and Geist, H. J., Springer, Berlin, Germany, 71-116, 2006.

Ellis, A., Ramirez, C., and Mac Donald, R. H.: Wetting capacity distribution in aggregates from soils with a different management, Food Agr. Environ., 1, 229-233, 2003.

Foley, J. A., DeFries, R., Asner, G. P., Barford, C., Bonan, G., Carpenter, S. R., Chapin, F. S., Coe, M. T., Daily, G. C., Gibbs, H. K., Helkowski, J. H., Holloway, T., Howard, E. A., Kucharik, C. J., Monfreda, C., Patz, J. A., Prentice, C. I., Ramankutty, N., and Snyder, P. K.: Global Consequences of Land Use, Science, 22, 570-574, 2005.

Fox, J., Truong, D. M., Rambo, A. T., Tuyen, N. P., Cuc, L. T., and Leisz, S.: Shifting cultivation: a new old paradigm for managing tropical forests, Bio Science, 50, 521-528, 2000.

Fritsch, J. M.: The hydrological effects of clearing tropical rain forest and of the implementation of alternative land uses, in: Hydrology of Warm Humid Regions, edited by: Gladwell, J. S., IAHS Publications, 216, 53-66, 1993.

Garcia, E.: Modificaciones al sistema de clasificación climática de Köppen, Offset Larios, México, D. F., México, 217 pp., 1988.

García-Franco, J. G., Castillo-Campos, G., Mehltreter, K., Martínez, M. L., and Vázquez, G.: Composición florística de un bosque mesófilo del centro de Veracruz, México, Bol. Soc. Bot. Mex., 83, 37-52, 2008.

Gash, J. H. C.: An analytical model of rainfall interception by forests, Q. J. Roy. Meteor. Soc., 105, 43-55, 1979.

Gash, J. H. C. and Shuttleworth, W. J.: Tropical deforestation: Albedo and the surface energy balance, Clim. Change, 19, 123$133,1991$.

Genereux, D.: Quantifying uncertainty in tracer-based hydrograph separations, Water Resour. Res., 34, 915-919, 1998.

Germer, S., Neill, C., Vetter, T., Chaves, J., Krusche, A. V., and Elsenbeer, H.: Implications of long-term land-use change for the hydrology and solute budgets of small catchments in Amazonia, J. Hydrol., 364, 349-363, 2009. 
Germer, S., Neill, C., Krusche, A. V., and Elsenbeer, H.: Influence of land-use change on near-surface hydrological processes: undisturbed forest to pasture, J. Hydrol., 380, 473-480, 2010.

Giambelluca, T. W.: Hydrology of altered tropical forest, Hydrol. Process., 16, 1665-1669, 2002.

Goldsmith, G. R., Muñoz-Villers, L. E., Holwerda, F., McDonnell, J. J., Asbjornsen, H., and Dawson, T. E.: Stable isotopes reveal linkages among ecohydrological processes in a seasonally dry tropical montane cloud forest, Ecohydrol., 5, 779-790, 2012.

Hamilton, L. S., Juvik, J. O., and Scatena, F. N.: Tropical Montane Cloud Forests, Ecological Studies 110, Springer Verlag, New York, 410 pp., 1995.

Hassler, S. K., Zimmermann, B., van Breugel, M., Hall, J. S., and Elsenbeer, H.: Recovery of saturated hydraulic conductivity under secondary succession on former pasture in the humid tropics, Forest Ecol. Manag., 26, 1634-1642, 2011.

Hewlett, J. D. and Hibbert, A. R.: Factors affecting the response of small watersheds to precipitation in humid areas, in: Forest Hydrology, edited by: Sopper, W. E. and Lull, H. W., Pergamon Press, New York, USA, 275-290, 1967.

Hölscher, D., Mackensen, J., and Roberts, J. M.: Forest recovery in the humid tropics: changes in vegetation structure, nutrient pools and the hydrological cycle, in: Forests, Water and People in the Humid Tropics, Cambridge University Press, Cambridge, 598$621,2005$.

Holwerda, F., Scatena, F. N., and Bruijnzeel, L. A.: Throughfall in a Puerto Rican lower montane rain forest: A comparison of sampling strategies, J. Hydrol., 327, 592-602, 2006.

Holwerda, F., Bruijnzeel, L. A., Muñoz-Villers, L. E., Equihua, M., and Asbjornsen, H.: Rainfall and cloud water interception in mature and secondary lower montane cloud forests of central Veracruz, Mexico, J. Hydrol., 384, 84-96, 2010.

Hongve, D.: A revised procedure for discharge measurement by means of the salt dilution method, Hydrol. Process., 1, 267-270, 1987.

Jipp, P. H., Nepstad, D. C., Cassel, D. K., and Reis de Carvalho, C.: Deep soil moisture storage and transpiration in forests and pastures of seasonally-dry Amazonia, Clim. Change, 39, 395412, 1998

Karlsen, R.: Stormflow processes in a mature tropical montane cloud forest catchment, Coatepec, Veracruz, Mexico. MSc. thesis, VU Univ., Amsterdam, Netherlands, 110 pp., 2010.

Kennedy, V. C., Zellweger, G. W., and Avanzino, R. J.: Variation of rain chemistry during storms at 2 sites in northern California, Water Resour. Res., 15, 687-702, 1979.

Kindsvater, C. E. and Carter, R. W. C.: Discharge characteristics of rectangular thinplate weirs, Journal of the Hydraulics Division, Proc. Am. Soc. Civil Eng., vol. 83 (HY6), Paper 1453, 1957.

Lambin, E. R., Geist, H. J., and Lepers, E.: Dynamics of land-use and land-cover change in tropical regions, Annu. Rev. Environ. Resour., 28, 205-241, 2003.

Malmer, A.: Water yield changes after clear-felling tropical rainforest and establishment of forest plantation in Sabah, Malaysia, J. Hydrol., 134, 77-94, 1992.

Marín-Castro, B.E.: Variación espacial de la conductividad hidráulica saturada en suelos de origen volcánico bajo tres usos de suelo en el centro de Veracruz, México. MSc. thesis, Posgrado en Ciencias, Instituto de Ecología, A.C., Xalapa, Veracruz, México, 108 pp., 2010.
McDonnell, J. J., Bonell, M., Stewart, M. K., and Pearce, A. J.: Deuterium variations in storm rainfall - Implications for stream hydrograph separation, Water Resour. Res., 26, 455-458, 1990.

McDonnell, J. J., Owens, I. F., and Stewart, M. K.: A case study of shallow flow paths in a steep zero-order basin: A physicalchemical isotopic analysis, Water Resour. Bull., 27, 679-685, 1991 a.

McDonnell, J. J., Stewart, M. K., and Owens, I. F.: Effect of catchment-scale subsurface mixing on stream isotopic response, Water Resour. Res., 27, 3065-3073, 1991b.

Molina, A., Govers, G., Vanacker, V., Poesen, J., Zeelmaekers, E., and Cisneros, F.: Runoff generation in a degraded Andean ecosystem: Interaction of vegetation cover and land use, Catena, 71, 357-370, 2007.

Moraes, J. M., Schuler, A. E., Dunne, T., Figueiredo, R. O., and Victoria, R. L.: Water storage and runoff processes in plinthic soils under forest and pasture in eastern Amazonia, Hydrol. Process., 20, 2509-2526, 2006.

Mosley, M. P.: Streamflow generation in a forested watershed, Water Resour. Res., 15, 795-806, 1979.

Muñoz-Piña, C., Guevara, A., Torres, J. M., and Braña, J.: Paying for the hydrological services of Mexico's forests: analysis, negotiations and results, Ecol. Econ., 65, 725-736, 2008.

Muñoz-Villers, L. E.: Efecto del cambio en el uso de suelo sobre la dinámica hidrológica y calidad de agua en el trópico húmedo del centro de Veracruz, México. Ph.D. thesis, Univ. Autónoma Metropolitana, México D.F., México, 262 pp., 2008.

Muñoz-Villers, L. E. and López-Blanco, J.: Land use/cover changes using Landsat TM/ETM images in a tropical and biodiverse mountainous area of central eastern Mexico, Int. J. Remote Sens., 29, 71-93, 2008.

Muñoz-Villers, L. E. and McDonnell, J. J.: Runoff generation in a steep, tropical montane cloud forest catchment on permeable volcanic substrate, Water Resour. Res., 48, W09528, doi:10.1029/2011WR011316, 2012.

Muñoz-Villers, L. E., Holwerda, F., Gómez-Cárdenas, M., Equihua, M., Asbjornsen, H., Bruijnzeel, L. A., Marín-Castro, B. E., and Tobón, C.: Water balances of old-growth and regenerating montane cloud forests in central Veracruz, Mexico, J. Hydrol., 462463, 53-66, 2012.

Ogunkoya, O. O. and Jenkins, A.: Analysis of storm hydrograph and flow pathways using a 3-component hydrograph separation model, J. Hydrol., 142, 71-88, 1993.

Olden, J. D. and Poff, N. L.: Redundancy and the choice of hydrologic indices for characterizing streamflow regimes, River Res. App., 19, 101-121, 2003.

Peel, M. C.: Hydrology: catchment vegetation and runoff, Progr. Phys. Geogr., 12, 1-8, 2009.

Pinder, G. F. and Jones, J. F.: Determination of ground-water component of peak discharge from chemistry of total runoff, Water Resour. Res., 5, 438-445, 1969.

Roa-Garcia, M.C. and Weiler, M.: Integrated response and transit time distributions of watersheds by combining hydrograph separation and long-term transit time modeling, Hydrol. Earth Syst. Sc., 14, 1537-1549, 2010.

Roa-García, M. C., Brown, S., Schreier, H., and Lavkulich, L. M.: The role of land use and soils in regulating water flow in small headwater catchments of the Andes, Water Resour. Res., 47, W05510, doi:10.1029/2010WR009582, 2011. 
Sawicz, K., Wagener, T., Sivapalan, M., Troch, P. A., and Carrillo, G.: Catchment classification: empirical analysis of hydrologic similarity based on catchment function in the eastern USA, Hydrol. Earth Syst. Sci., 15, 2895-2911, doi:10.5194/hess-15-28952011, 2011.

Sayama, T., McDonnell, J. J., Dhakal, A., and Sullivan, K.: How much water can a watershed store?, Hydrol. Process., 25, 38993908, 2011.

Scatena, F. N., Bruijnzeel, L. A., Bubb, P., and Das, S.: Setting the stage, in: Tropical Montane Cloud Forests: Science for Conservation and Management, edited by: Bruijnzeel, L. A., Scatena, F. N., and Hamilton, L. S., Cambridge Univ. Press, UK, 3-13, 2010.

Scheffler, R., Neill, C., Krusche, A. V., and Elsenbeer, H.: Soil hydraulic response to land-use change associated with the recent soybean expansion at the Amazon agricultural frontier, Agr., Ecosyst. Environ., 144, 281-289, 2011.

Scullion, J., Thomas, C. W., Vogt, K. A., Pérez-Maqueo, O., and Logsdon, M. G.: Evaluating the environmental impact of payments for ecosystem services in Coatepec (Mexico) using remote sensing and on-site interviews, Environ. Conserv., 38, 426-434, 2011.

Sidle, R. C.: Stormflow generation in forest headwater catchments: a hydrogeomorphic approach, For. Snow Landsc. Res., 80, 115128, 2006.

Sidle, R. C., Tsuboyama, Y., Noguchi, S., Hosoda, I., Fujieda, M., and Shimizu, T.: Stormflow generation in steep forested headwaters: A linked hydrogeomorphic paradigm, Hydrol. Process., 14, 369-385, 2000.

Sklash, M. G. and Farvolden, R. N.: Role of groundwater in storm runoff, J. Hydrol., 43, 45-65, 1979.

Tobón, C., Bruijnzeel, L. A., Frumau, F. K. A., and Calvo-Alvarado, J. C.: Changes in soil physical properties after conversion of tropical montane cloud forest to pasture in northern Costa Rica, in: Tropical Montane Cloud Forests, Science for Conservation and Management, edited by: Bruijnzeel, L. A., Scatena, F. N., and Hamilton, L. S., Cambridge Univ. Press, Cambridge, UK, 502$515,2010$.

Toebes, C. and Strang, D. D.: On recession curves 1 - recession equations, J. Hydrol. (New Zealand), 3, 2-14, 1964.
Tognetti, S., Aylward, B., and Bruijnzeel, L. A.: Assessment needs to support the development of arrangements for Payments for Ecosystem Services from tropical montane cloud forests, in: Tropical Montane Cloud Forests. Science for Conservation and Management, edited by: Bruijnzeel, L. A., Scatena, F. N., and Hamilton, L. S., Cambridge Univ. Press, Cambridge, UK, 671685, 2010.

Van Osch, F. P.: Seasonal hydrologic response to land use change and climate change in a tropical montane cloud forest in Veracruz, Mexico. MSc. Thesis, Universiteit Utrecht, The Netherlands, 90 pp., 2010.

Viessman, W., Lewis, G. L., and Knapp, J. W.: Introduction to Hydrology, HarperCollins, New York, 415 pp., 1989.

Xu, J., Fox, J., Xing, L., Podger, N., Leisz, S., and Xihui, A.: Effects of swidden cultivation, population growth, and state policies on land cover in Yunnan, China, Mt. Res. Dev., 19, 123-132, 1999.

Zadroga, F.: The hydrological importance of a montane cloud forest area of Costa Rica, in: Tropical Agricultural Hydrology, edited by: Lal, R. and Russell, E. W., John Wiley and Sons, New York, N.Y., 59-73, 1981.

Zhang, L., Dawes, W. R., and Walker, G. R.: Response of mean annual evapotranspiration to vegetation changes at catchment scale, Water Resour. Res., 37, 701-708, 2001.

Zhang, Z., Wagener, T., Reed, P., and Bhushan, R.: Reducing uncertainty in predictions in ungauged basins by combining hydrologic indices regionalization and multiobjective optimization, Water Resour. Res., 44, W00B04, doi:10.1029/2008WR006833, 2008.

Ziegler, A. D., Giambelluca, T. W., Tran, L. T., Vana, T. T., Nullet, M. A., Fox, J., Vien, T. D., Pinthong, J., Maxwell, J. F., and Evett, S.: Hydrological consequences of landscape fragmentation in mountainous northern Vietnam: evidence of accelerated overland flow generation, J. Hydrol., 287, 124-146, 2004.

Zimmermann, B., Elsenbeer, H., and De Moraes, J. M.: The influence of land-use changes on soil hydraulic properties: implications for runoff generation, Forest Ecol. Manag., 222, 29-38, 2006.

Zimmermann, B., Papritz, A., and Elsenbeer, H.: Asymmetric response to disturbance and recovery: Changes of soil permeability under forest-pasture-forest transitions, Geoderma, 159, 209215, 2010. 